\title{
ÂNFORAS REPUBLICANAS DE MONTE MOLIÃO (LAGOS, ALGARVE, PORTUGAL)
}

\section{ROMAN REPUBLICAN AMPHORAE FROM MOLIÃO (LAGOS, ALGARVE, PORTUGAL)}

\author{
ANA MARGARIDA ARRUDA* \\ ELISA DE SOUSA*
}

\begin{abstract}
Resumo: As escavações arqueológicas levadas a efeito em Monte Molião, no Algarve litoral, evidenciaram uma extensa ocupação romano/republicana, cujo início foi possível datar do último quartel do século II a.n.e. Do conjunto dos materiais recolhidos nos níveis correspondentes a esta ocupação, destacam-se as ânforas, que apresentam uma considerável variedade tipológica e expressiva diversidade áreas produtoras, bem como de conteúdos. O estudo que concretizámos mostrou uma significativa dependência do sítio algarvio dos produtos alimentares oriundos da área de Cádis, que se constituiu como o centro exportador por excelência, situação que é particularmente evidente a partir dos finais do século II a.n.e. O vinho itálico e os produtos norte africanos foram também importantes, mas sobretudo na fase inicial da ocupação.
\end{abstract}

Palabras claves: Algarve, comércio, romano/republicano, ânforas, romanização.

\section{INTRODUÇÃO}

Monte Molião localiza-se no Algarve, concelho de Lagos, na margem esquerda da Ribeira de Bensafrim (fig. 1). Trata-se de uma colina de forma ovalada, que se destaca bem na paisagem e de onde se

* UNIARQ (Centro de Arqueologia. Universidade de Lisboa). Faculdade de Letras. 1600-214. Lisboa (Portugal). Correo-e: a.m.arruda@fl.ul.pt, el@fl.ul.pt.

\begin{abstract}
Archaeological excavations carried out in Monte Molião, in the Algarve coast, showed an extensive Republican/Roman occupation, started in the last quarter of II century b.c.e. Between the materials collected at the levels corresponding to this occupation, the amphorae are numerous and exhibit a considerable variety concerning typology, producing areas and content. The study of those amphorae showed a significant dependence of the site from Cadiz area, which is the exporting center for excellence, a situation that is particularly evident in the late second century b.c.e. Italic wine and North Africans products are also important, but especially in the beginning of the occupation.
\end{abstract}

Key words: Algarve, trade, roman/republican, amphorae, romanization.

domina visualmente toda a baía de Lagos (fig. 2). O estudo do sítio arqueológico de Monte Molião tem vindo a ser concretizado através da publicação de textos de síntese de carácter mais geral (Arruda 2007, Arruda et al. 2008), de artigos que incidem sobre aspectos particulares da sua ocupação humana (Arruda et al. 2010, Arruda e Pereira 2010), ou ainda de estudos sobre materiais específicos (Dias 2010, Lourenço 2010).

$\mathrm{O}$ artigo que agora se publica insere-se neste último grupo de trabalhos, estudando-se aqui as ânforas 


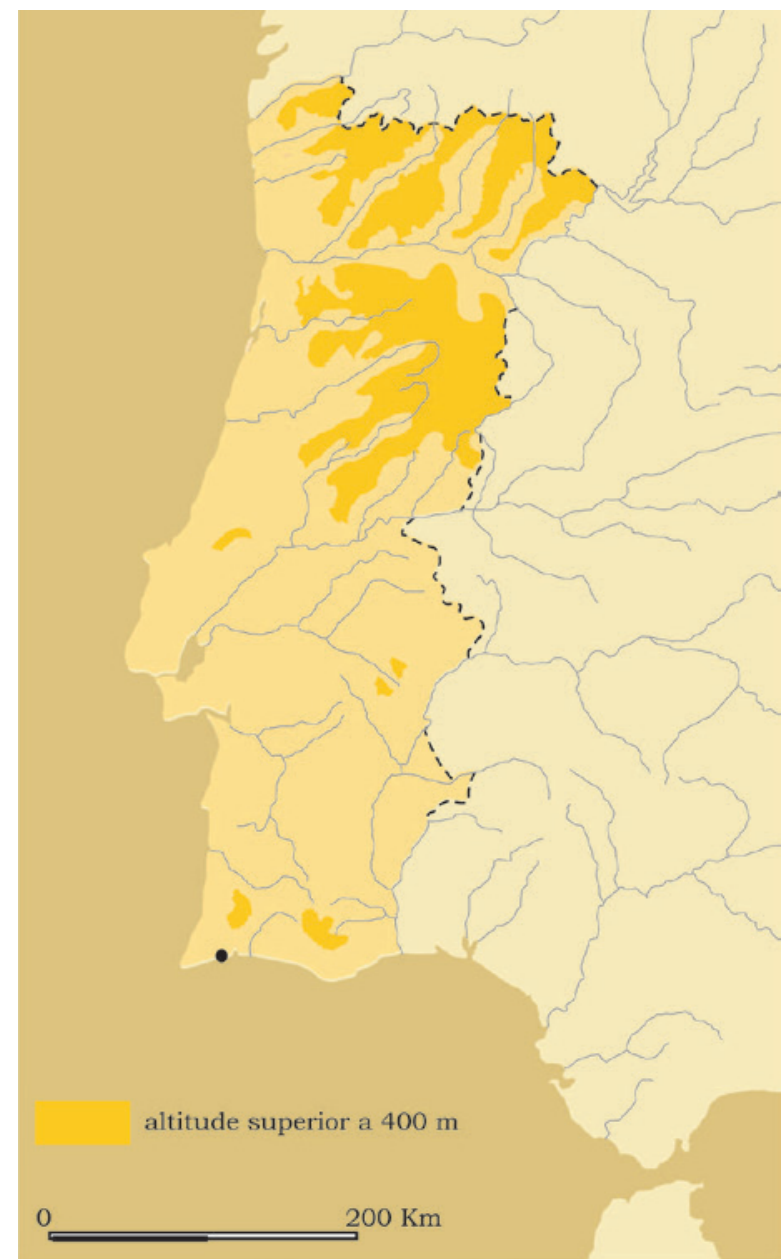

Figura 1. Monte Molião (Algarve) no território actualmente português (base cartográfica de V. Gonçalves). de época republicana recuperadas no sítio, ao longo das cinco campanhas de escavação que já tiveram lugar, desde 2006. Deve, contudo, esclarecer-se, desde já, que apenas os exemplares que foram recolhidos em contextos arqueológicos seguros foram devidamente tratados, ainda que se possa fazer, em determinadas situações, referência a outros descontextualizados. Esta opção determinou também a apresentação desses mesmos contextos, até porque outros materiais deles oriundos ajudaram a precisar cronologias e facilitaram uma leitura global e associada dos materiais anfóricos.

Os referidos contextos, bem como naturalmente as ânforas aqui apresentadas, foram escavados em Monte Molião ao longo das cinco extensas campanhas de escavação, que totalizaram uma área de cerca de $800 \mathrm{~m}^{2}$. Estas intervenções foram concretizadas no quadro do Projecto de Investigação que o Centro de Arqueologia da Universidade de Lisboa (UNIARQ, Portugal) implantou para o sítio no âmbito de um Protocolo assinado entre a Câmara Municipal de Lagos, a Faculdade de Letras e a UNIARQ.

Outros trabalhos arqueológicos no sítio forneceram informação sobre a sua ocupação republicana, concretamente os que foram conduzidos pela empresa $\mathrm{Pa}$ limpsesto no sopé nordeste, estando alguns resultados já publicados (Sousa e Serra 2006).

Monte Molião está intimamente relacionado com a questão da localização da Laccobriga das fontes clássicas, situação que não pode ser esquecida no contexto da sua ocupação republicana, uma vez que Plutarco localizou nesse oppidum lusitano um dos mais célebres episódios das guerras sertorianas.

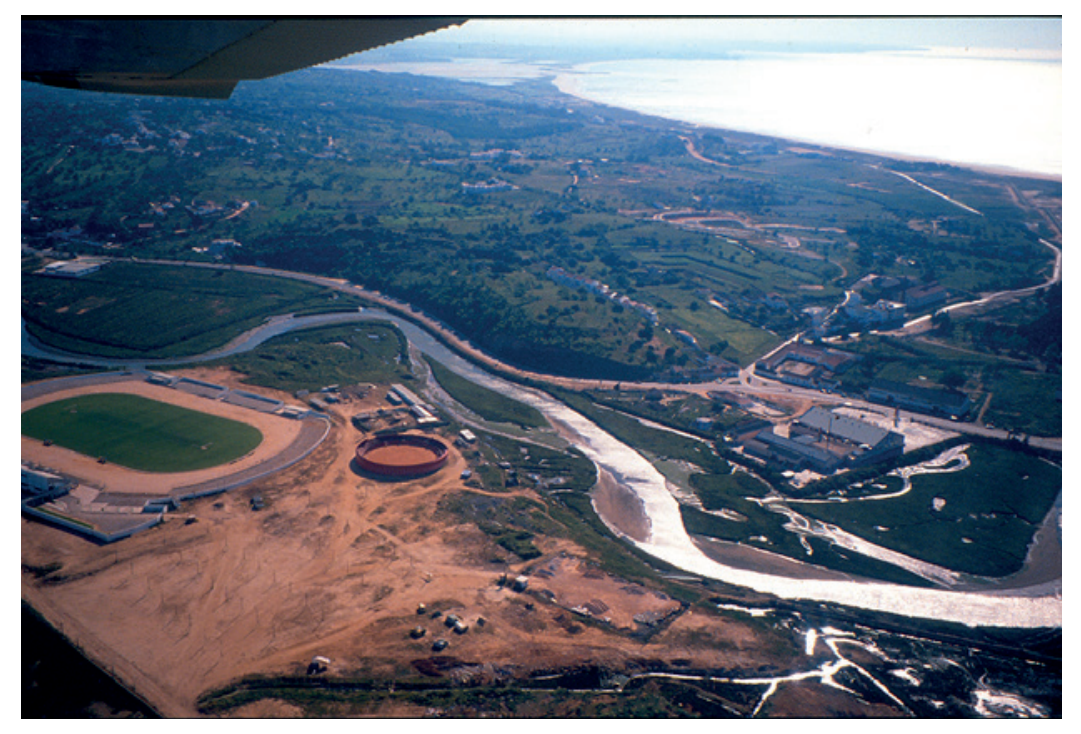

Figura 2. Vista aérea de Monte Molião (foto de Rui Parreira). 


\section{AS FASES REPUBLICANAS DE MONTE MOLIÃO}

Em dois dos sectores escavados em Monte Molião, concretamente o A e o $\mathrm{C}$, foi possível documentar, contextualmente, uma ocupação de época republicana, que se materializava em materiais e construções. Contudo, enquanto no último sector se tornou possível identificar compartimentos organizados em torno de espaços de circulação, que formam globalmente um conjunto urbanístico relativamente coerente, no sector A, este momento foi apenas registado sob os alicerces do que foi designado por compartimento 2 , datado de época imperial, e em escassos espaços entre o urbanismo imperial e o estradão que, nos anos 80 do século XX, destruiu o sítio na sua vertente este (fig. 3).

Neste último sector, os depósitos republicanos eram particularmente espessos, tendo sido possível individualizar contextos concretos que se sobrepunham, pelo menos no compartimento 2, e nos espaços compreendidos entre este e a rua do Molião, bem como no exterior do compartimento 3. No primeiro caso, sobre o pavimento (U.E.) [191], depositaram-se várias de camadas de cronologia republicana, que correspondem às seguintes U.E.s: [197], [184], [183], [185], [172], [173], [171], [175], [170], [165] e [159]. Para o segundo, temos disponível para análise os dados recuperados nas U.E.s [163], [167], [168], [174] e [187] (fig. 4).

Como veremos, quer as ânforas quer os restantes materiais associados a estas Unidades Estratigráficas indiciam um momento de ocupação consideravelmente uniforme, havendo dados que permitem concluir que alguns destes estratos se formaram num momento relativamente curto e próximo entre si. De facto, o estado de conservação das peças, bem como a circunstância de algumas das ânforas recuperadas se encontrarem ocas,

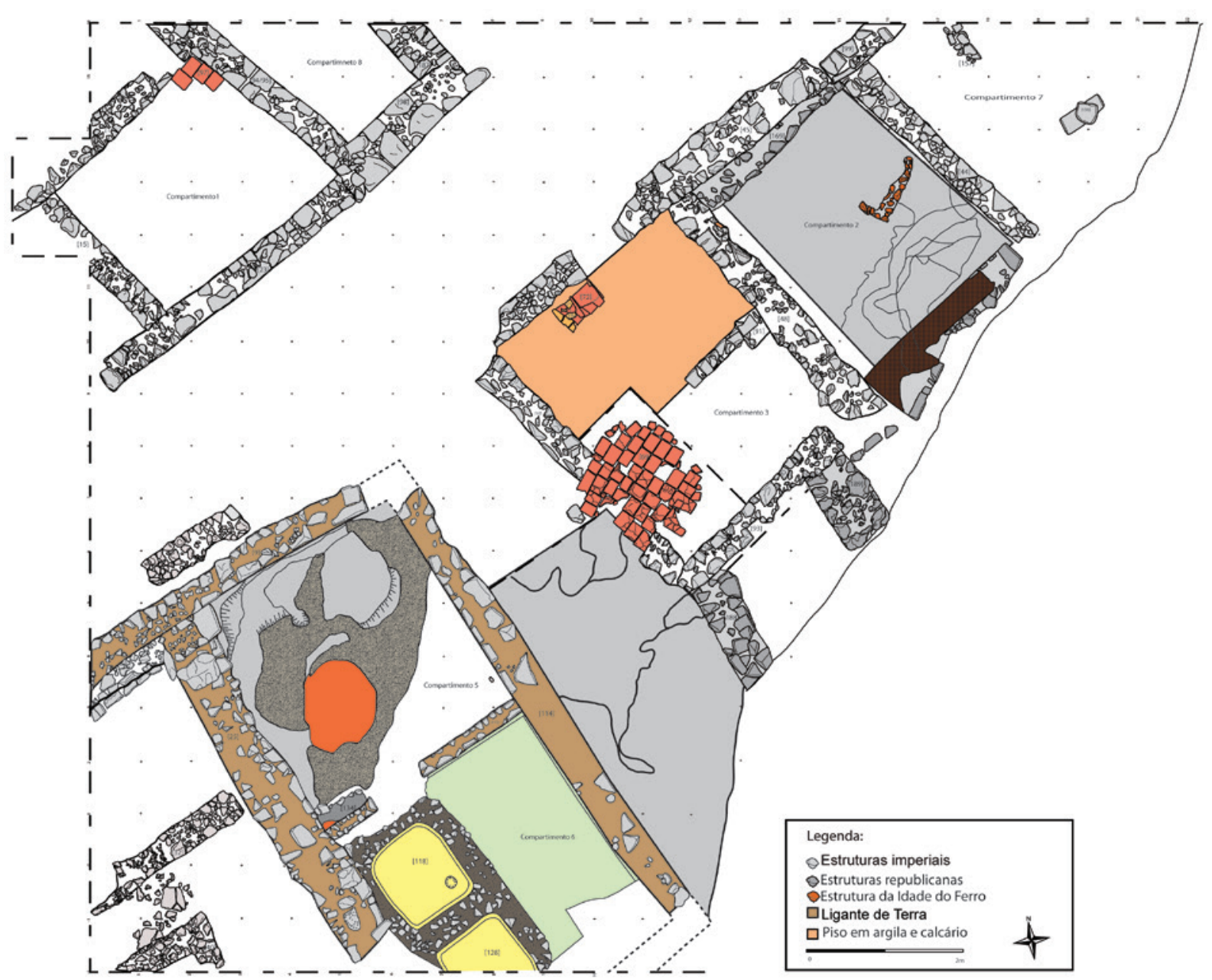

Figura 3. Planta da área escavada no Sector A. 


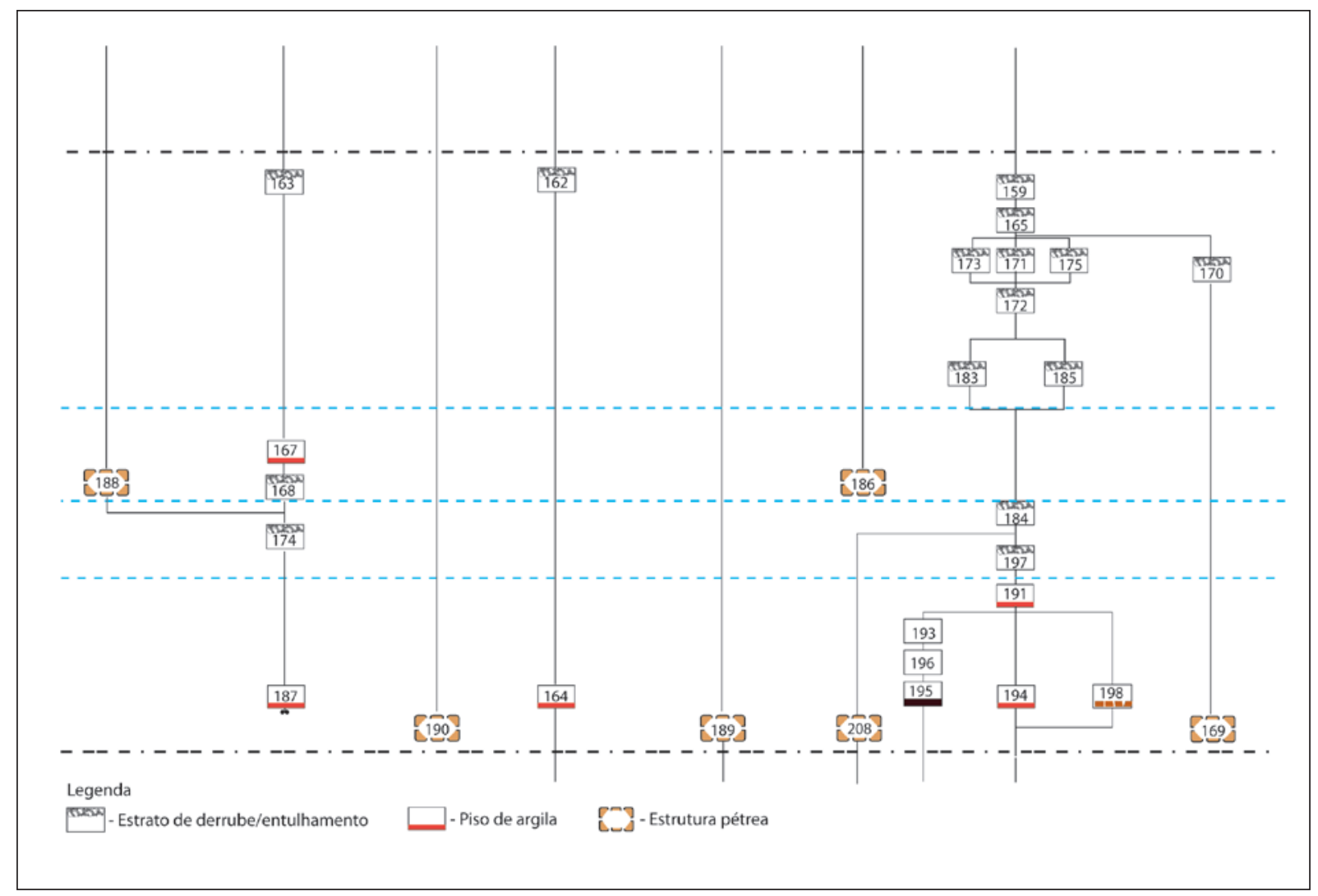

Figura 4. Matriz estratigráfica da ocupação republicana do Sector A.

ou seja praticamente sem sedimento no seu interior, parece provar uma rápida formação dos níveis arqueológicos (fig. 5).

Os dados da escavação comprovaram também que houve pelo menos dois momentos construtivos, que pudemos associar a U.E.s específicas. Assim, as camadas que cobrem o pavimento U.E. [191] ([184], [183], [185], [172], [197]), onde foram recuperados materiais fracturados in situ, encostam às paredes [169] e [208]. Sobre estes níveis construíram-se os muros nordeste [44] e sudoeste [48], os quais estavam relacionados com a U.E. [165], [173], [171], [175] e [159].

Também no exterior, ou seja entre os compartimentos 2 e 3 e a Rua do Molião, foram identificados contextos republicanos com características idênticas, concretamente ânforas praticamente completas e sem sedimento no interior.

Como já acima fizemos referência, a formação destes estratos parece ter ocorrido de forma repentina, e, apesar de ter sido possível identificar duas fases construtivas, a verdade é que não é claro que entre elas tenha decorrido um espaço de tempo superior a 30/40anos. Por outro lado, e como veremos, também os espólios, concretamente as ânforas, indicam um espaço de tempo de utilização de cerca de quatro décadas. Assim, e ainda que seja tentador separar a U.E. [159] (a primeira a ser escavada e a última a ser formada) da [165] (a que se lhe sobrepõe), e esta última das [184] e da [172] (as últimas a serem escavadas, as primeiras a serem formadas, sobre o pavimento [191]), a verdade é que a sua separação em termos cronológicos, e portanto da sua constituição, é muito problemática, atendendo a que a grande maioria dos materiais arqueológicos recuperados em todas elas apresenta similitudes morfológicas e de fabrico. Ainda assim, não podemos escamotear o facto de os níveis inferiores ([184] e [172]) fornecerem apenas campaniense A, ao contrário do que se passa nos superiores, onde já ocorrem fabricos de Cales. Por outro lado, as ânforas inteiras que foram recuperadas nas unidades [165] e [163] correspondem a formas greco-itálicas de transição e a que foi recolhida na [159] é já uma Dressel 1 clássica. Estes dados poderiam indiciar uma sequência cronológica para a formação destas unidades estratigráficas, 


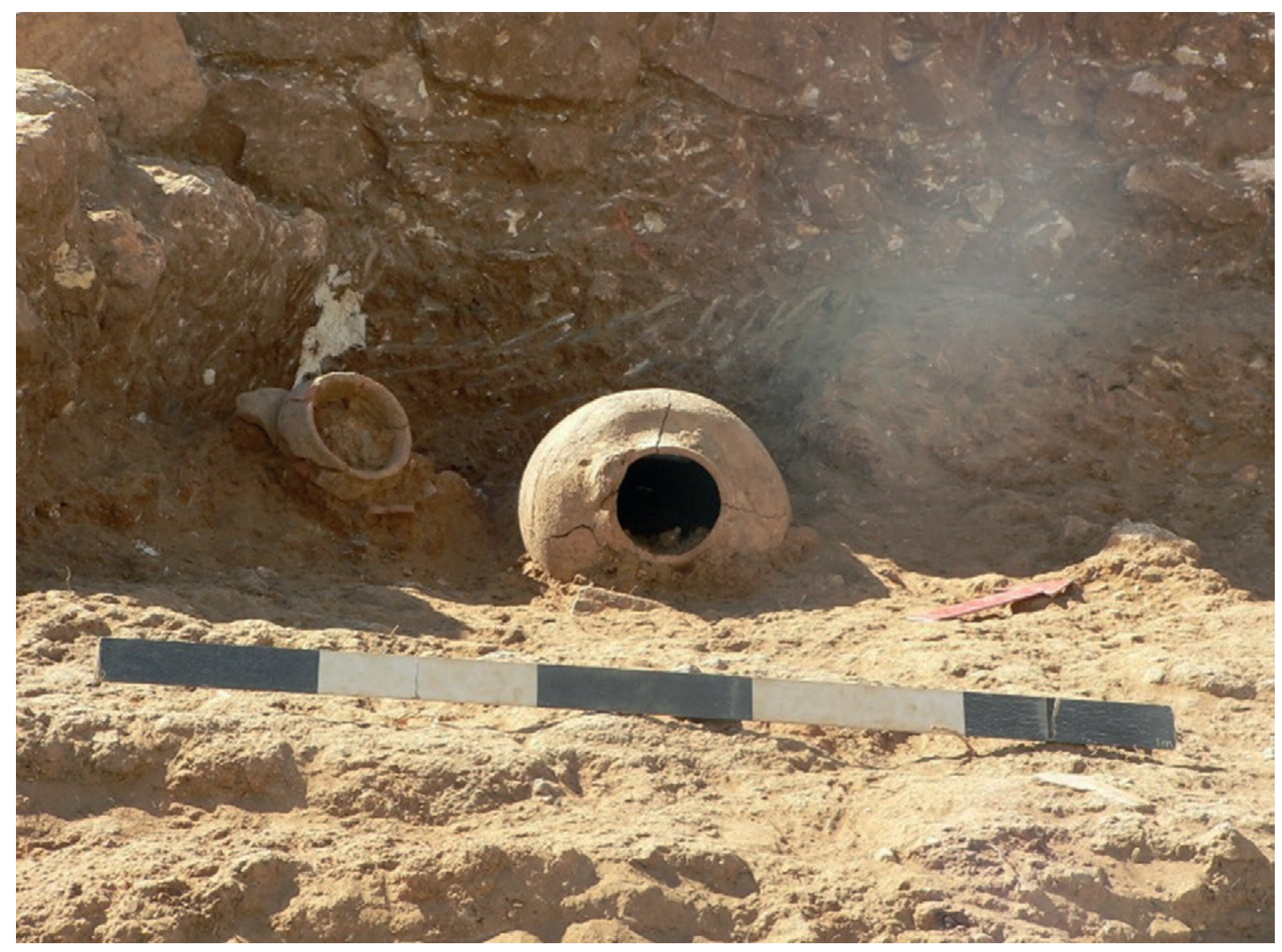

Figura 5. Ânforas recuperadas na U.E. [163].

uma vez que também boa parte dos materiais recolhidos parecem indiciar uma maior antiguidade dos níveis inferiores relativamente aos recolhidos nos superiores. Contudo, a formação das diversas unidades parece de facto ser coeva, parecendo-nos difícil assumir essa mesma sequência, justamente porque a deposição das ânforas, inteiras, sem sedimento no interior ainda que de morfologia diversa, deve ter ocorrido num mesmo momento.

No Sector C, a realidade é mais fácil de analisar, porque foi possível escavar em extensão uma larga área que não foi afectada pelas construções de época imperial (fig. 6). Por outro lado, e ainda que os materiais anfóricos não estivessem, na generalidade, tão bem conservados como os recolhidos no Sector A, a ocupação está plasmada numa arquitectura que pudemos abordar de forma faseada, o que permitiu, neste caso, leituras relativamente mais claras da realidade. Assim, e ainda que o número de Unidades Estratigráficas seja incomparavelmente maior (92 U.E.s), a verdade é que as suas relações e os seus conteúdos materiais são consideravelmente mais perceptíveis (fig. 7).

Neste Sector, foram registados dois grupos de compartimentos, estruturados em função de uma área aberta, que podem, todavia, corresponder a uma única unidade residencial. Este núcleo, que foi construído no primeiro momento de ocupação republicana desta área (Fase 1), foi posteriormente remodelado e acrescetado (Fase 2). Infelizmente, não foi possível estabelecer uma equivalência precisa entre as fases construtivas reconhecidas nos sectores $\mathrm{A}$ e $\mathrm{C}$, sendo ainda incerto se integram, ou não, os mesmos momentos cronológicos.

Assim, a análise do conjunto anfórico de acordo com um faseamento concreto foi realizada apenas na leitura estratigráfica do Sector C. Aqui, as ânforas puderam, com efeito, ser inventariadas de acordo com as fases arquitectónicas identificadas, tendo sido assim possível observar as diferenças e as semelhanças ao nível dos produtos alimentares importados pelo sítio ao longo da diacronia republicana. 


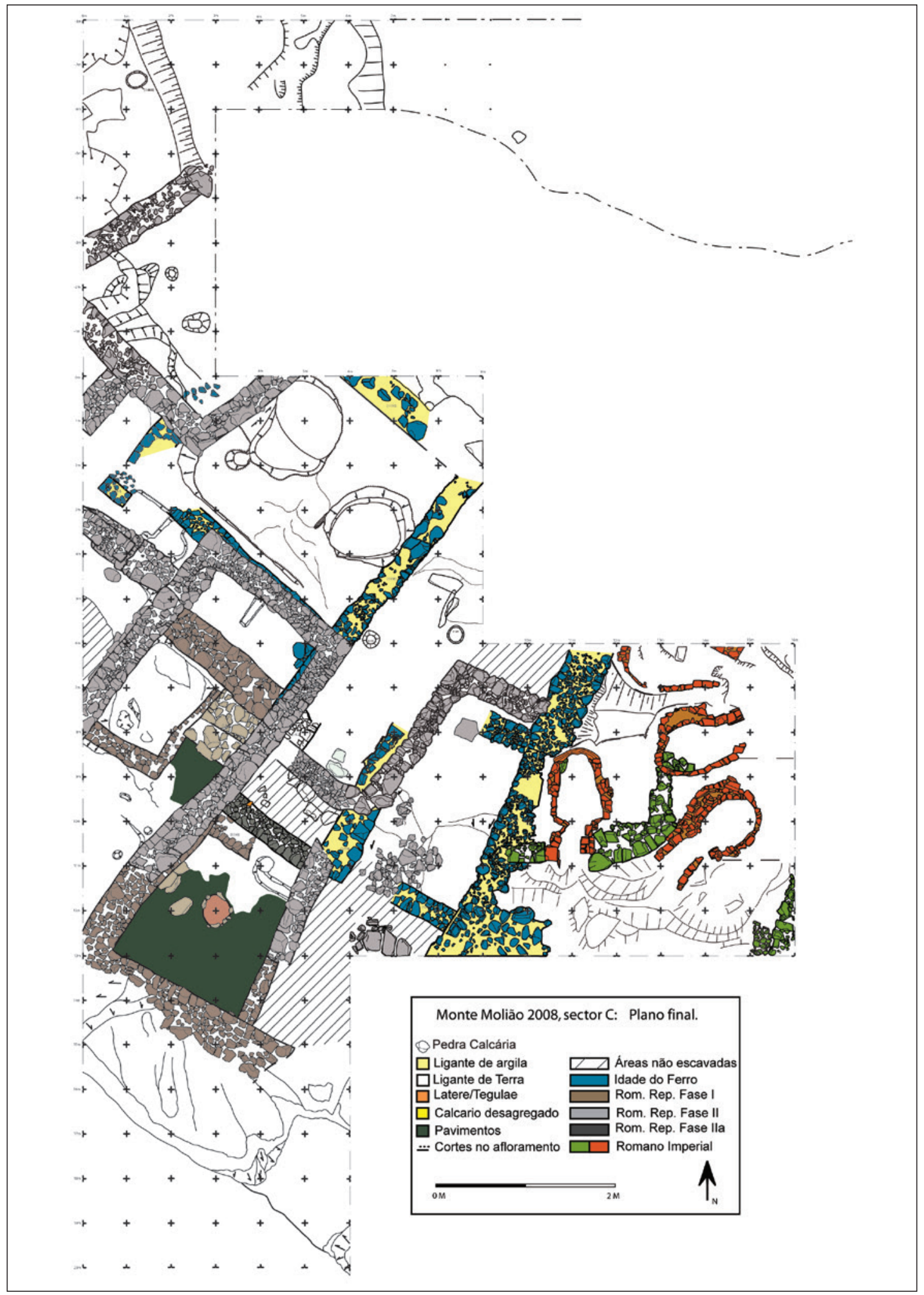

Figura 6. Planta da área escavada no Sector C. 


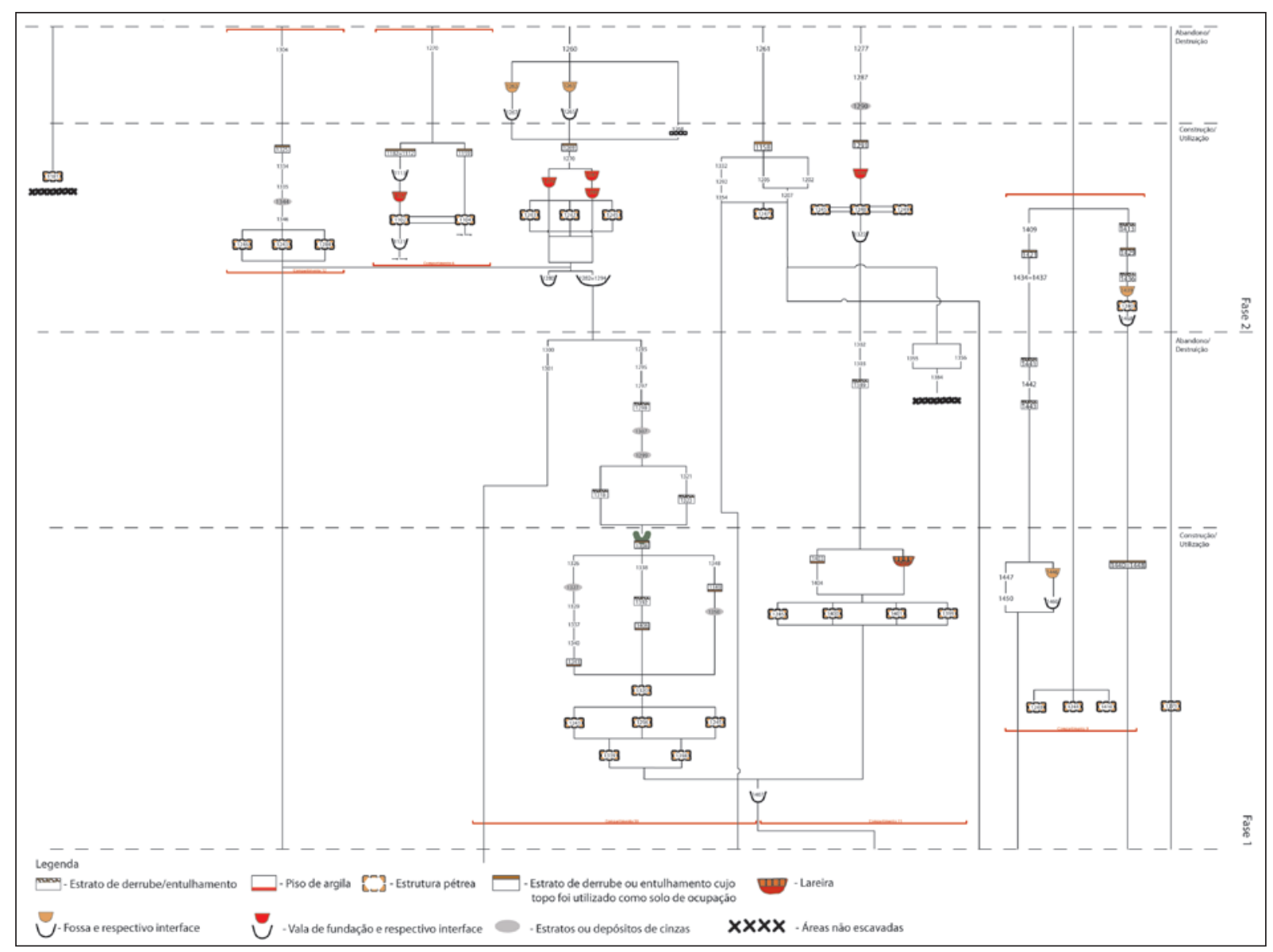

Figura 7. Matriz estratigráfica da ocupação republicana do Sector C.

\section{AS ÂNFORAS}

\subsection{A amostra}

As ânforas de época republicana são abundantes em Monte Molião, sendo o conjunto diversificado quanto à origem, à morfologia e aos conteúdos transportados.

Em contextos primários de ocupação, foram recolhidos 235 indivíduos, que foram estudados de acordo com a área de produção, concretamente Itália, norte de África (Cartago-Tunes e Tripolitânia) e área gaditana (fig. 8). Alguns exemplares, porém, apresentam características de fabrico que não permitiram a sua classificação de acordo com centros de produção concretos, pelo que se consideraram de "produção indeterminada". Outros integram a categoria designada por "material intrusivo/residual", por corresponderem, muito possivelmente, a intrusões mais recentes ou mais antigas em relação à cronologia de formação da unidade estratigráfica.
No total, e quanto aos centros exportadores, verificamos um absoluto predomínio das ânforas sud-hispânicas sobre as restantes $(46,81 \%$ da área de Cádis, para $24,26 \%$ itálicas e $11,06 \%$ norte africanas). As indeterminadas correspondem a $6,38 \%$ do conjunto. Os materiais intrusivos/residuais representam os restantes $11,49 \%$.

No que se refere às formas e à sua relação com os centros produtores, podemos adiantar desde já o seguinte:

1. Os fabricos itálicos, mais exactamente da costa tirrénica, sendo numerosos (24,26\%), estão representados por apenas duas formas: Greco-itálica $(8,77 \%)$ e Dressel 1 (66,67\%), estas últimas dominantes. Os contentores de forma indeterminada (que correspondem, seguramente, a um dos dois tipos anteriores) constituem $24,56 \%$ das importações itálicas. Dois fragmentos, infelizmente recolhidos fora do seu contexto primário, atestam a importação de produtos alimentares produzidos na costa adriática da Península Itálica. Trata-se de bordos integráveis na forma Lamboglia 2 (fig. 29), que, no entanto, não 


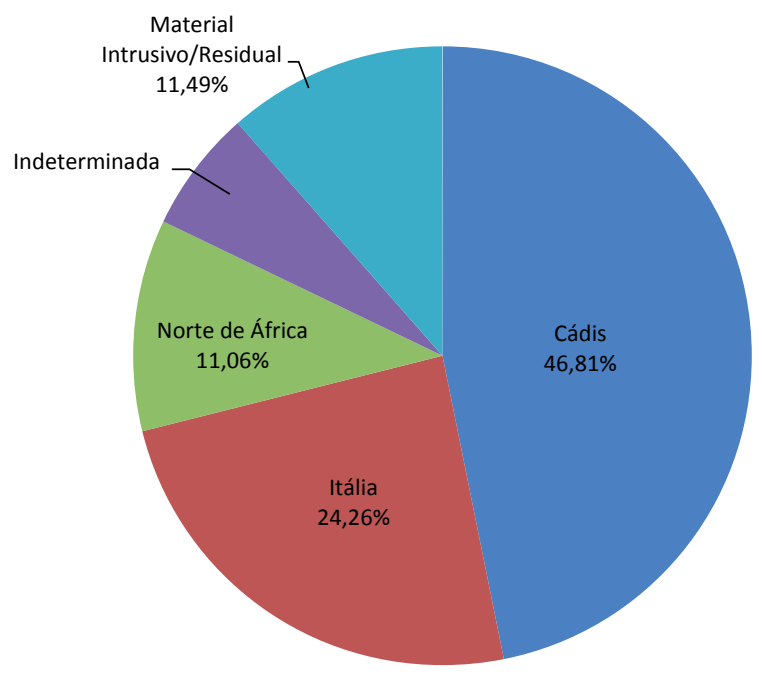

Figura 8. Distribuição do conjunto anfórico recolhido em contextos republicanos de acordo com a área de produção (base NMI).

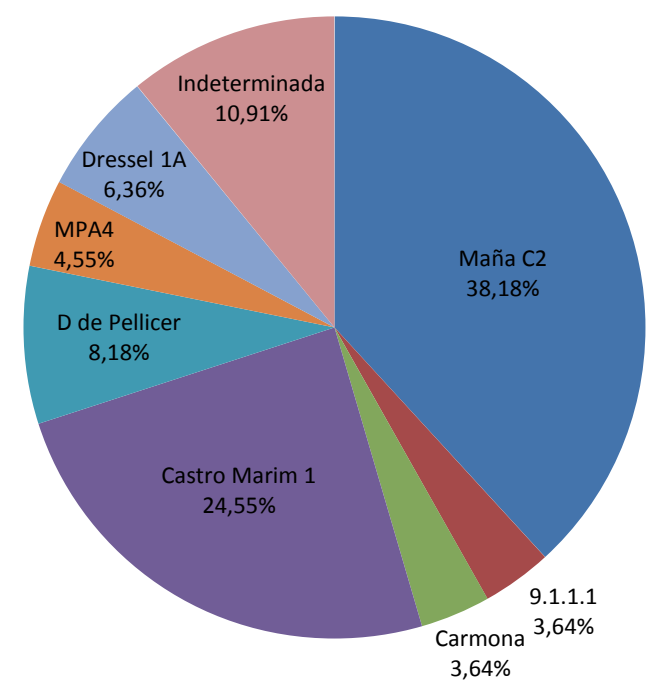

Figura 10. Distribuição das produções gaditanas segundo os tipos morfológicos (base NMI).

serão tratadas neste trabalho com muito detalhe e são muito raros no sítio, como aliás sucede também no restante território português (fig. 9).

2. A área da baía de Cádis foi maior centro abastecedor de Monte Molião, sendo a forma Mañá C2 a que domina sobre todas as outras $(38,18 \%)$, seguida de perto pela Castro Marim 1 (24,55\%). As restantes, D de Pellicer (8,18\%), Dressel 1 (6,36\%), Mañá Pascual A4 (4,55\%), 9.1.1.1. (3,64\%), Carmona

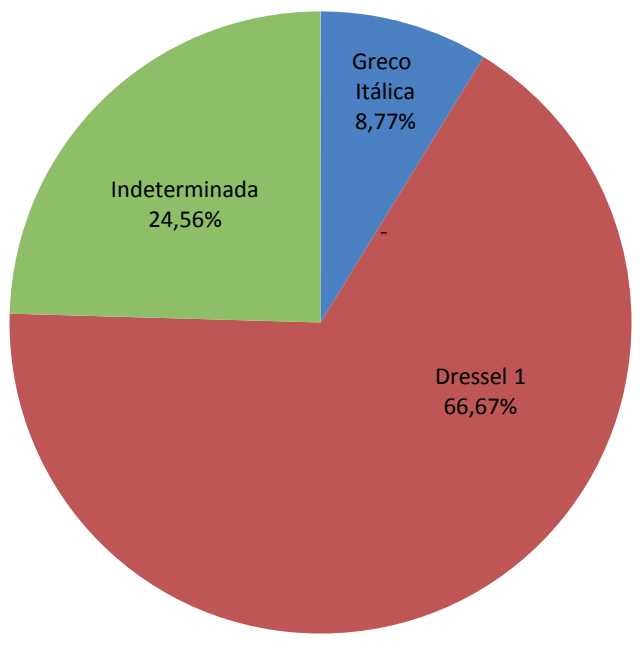

Figura 9. Distribuição das produções itálicas segundo os tipos morfológicos (base NMI).

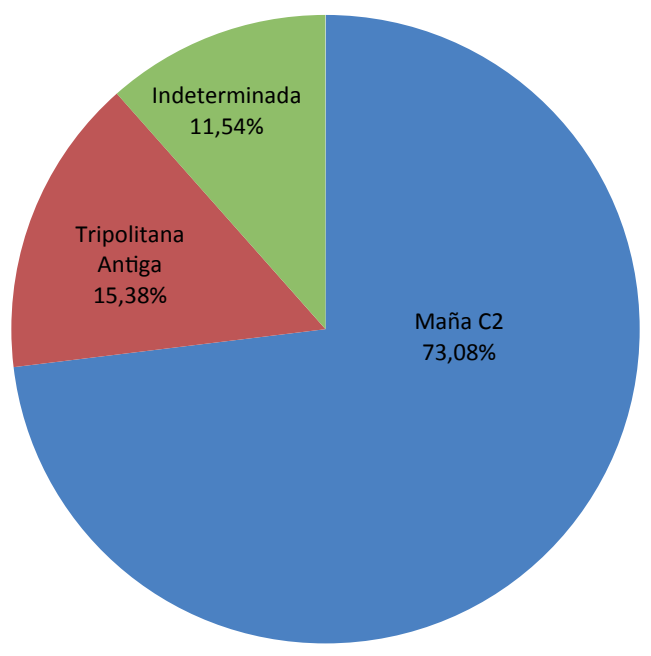

Figura 11. Distribuição das produções africanas segundo os tipos morfológicos (base NMI).

(3,64\%), estão representadas por escassos exemplares. As de forma indeterminada contabilizam 10,91\% (fig. 10).

3. O Norte de África também contribuiu de forma considerável para o abastecimento do sítio algarvio, estando as Mañá C2 muito bem documentadas (73,08\%), sendo as Tripolitanas Antigas em menor número $(15,38 \%)$. As indeterminadas correspondem a $11,54 \%$ do conjunto (fig. 11). 


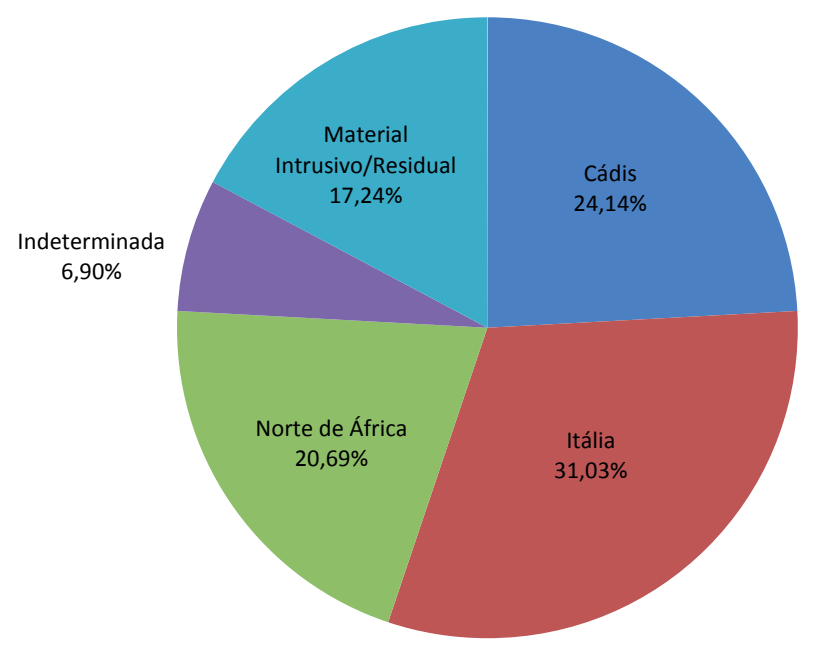

Figura 12. Distribuição das ânforas dos contextos republicanos da $1^{\mathrm{a}}$ fase do Sector $\mathrm{C}$, de acordo com a área de produção (base NMI).

Relativamente ao faseamento destas produções, e tendo em consideração as observações estratigráficas verificadas no Sector $\mathrm{C}$, deve desde já dizer-se que as três áreas abastecedoras de produtos alimentares não se diferenciam nitidamente em termos numéricos nos níveis correspondentes à primeira fase da ocupação republicana, ainda que a Península Itálica se destaque ligeiramente. De facto, as importações da área de Cádis estão representadas por 24,14\%, distribuídos pelas formas Mañá C2 (6 NMI), 9.1.1.1. (1 NMI), Carmona (1 NMI), Castro Marim 1 (1 NMI), D de Pellicer (2 $\mathrm{NMI}$ ) e formas indeterminadas (3 NMI); as itálicas por 31,03\%, concretamente Greco-Itálicas (1 NMI), Dressel 1 (11 NMI) e indeterminadas (6 NMI); as africanas por 20,79\% (Mañá C2-11 NMI e forma indeterminada - 1 NMI). Os exemplares de produção indeterminada representam 6,90\% (4 NMI) e os materiais intrusivos/ residuais os restantes 17,24\% (10 NMI) (fig. 12).

$\mathrm{Na}$ segunda fase, as importações da área de Cádis passam a dominar de forma absoluta, com 56,20\% (Mañá C2 - 29 NMI, 9.1.1.1. - 2 NMI, Carmona 1 NMI, Castro Marim 1 - 16 NMI, D de Pellicer -6 NMI, Mañá Pascual A4 - 4 NMI, Dressel 1 - 2 NMI, formas indeterminadas $-8 \mathrm{NMI}$ ), diminuindo, significativamente, as importações itálicas, com 21,49\% (Greco-Itálicas - 3 NMI, Dressel 1 - 19, formas indeterminadas - $4 \mathrm{NMI}$ ), e as norte africanas, agora com 5,79\% (Mañá C2 - 5 NMI, Tripolitana Antiga - 1 NMI, forma indeterminada - $1 \mathrm{NMI}$ ). As ânforas que não

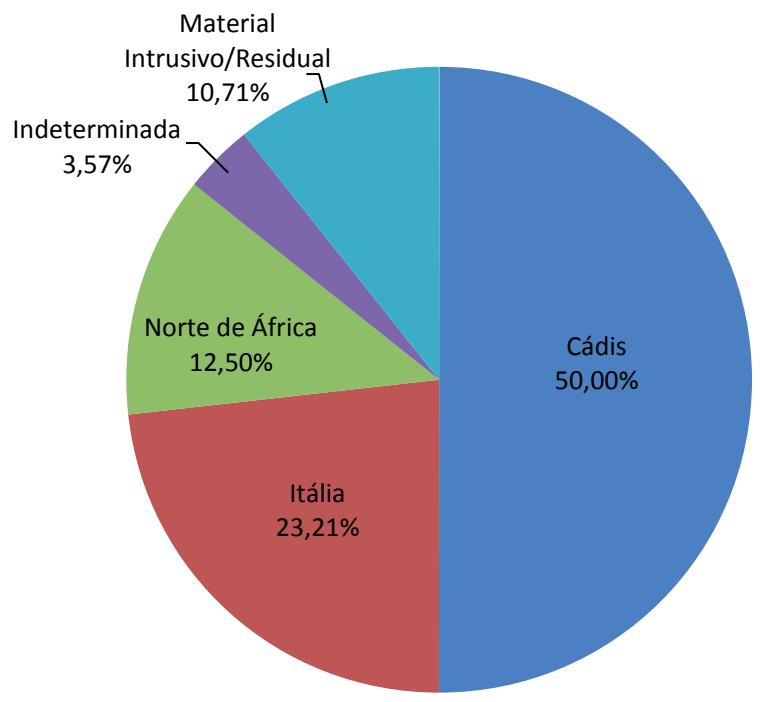

Figura 13. Distribuição das ânforas dos contextos republicanos da $2^{\mathrm{a}}$ fase do Sector $\mathrm{C}$, de acordo com a área de produção (base NMI).

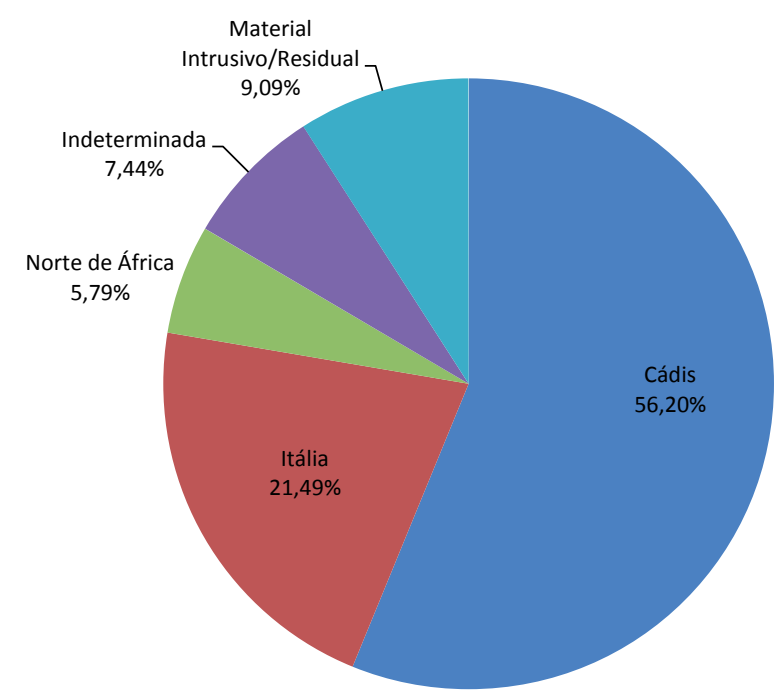

Figura 14. Distribuição das ânforas dos contextos republicanos do Sector A, de acordo com a área de produção (base NMI).

permitiram uma adscrição concreta do local de produção constituem $7,44 \%$ e as consideradas intrusivas/residuais os restantes $9,09 \%$ (fig. 13).

Não tendo sido possível, pelas razões já anteriormente referidas, uma diferenciação faseada das ânforas da ocupação republicana do Sector A, resta-nos apresentar os dados globais obtidos. Assim, as importações gaditanas representam $50 \%$, as itálicas $23,21 \%$, as norte africanas $12,50 \%$ e as de produção indeterminada 3,57\% (fig. 14). 


\subsection{As ânforas itálicas}

O conjunto das ânforas itálicas devidamente contextualizadas de Monte Molião é constituído por 57 indivíduos que se distribuem pelos dois sectores com ocupação republicana, o A (13 NMI) e o C (44 NMI) (fig. 15 a 20). Percentualmente, correspondem a $24,26 \%$ do conjunto anfórico estudado.

Trata-se de peças que se integram em dois tipos diversos, concretamente o Greco-Itálico (5 NMI $8,77 \%$ ) e o Dressel 1 (38 NMI - 66,67\%), sendo estas últimas claramente dominantes. Outros elementos de ânforas itálicas recuperados em Monte Molião poderão ainda pertencer a qualquer um destes dois tipos (14 NMI - 24,56\%).

Deve ainda referir-se que dos 13 indivíduos de produção itálica do Sector A que se encontraram devidamente contextualizados, dez foram recuperados no mesmo espaço, concretamente no que se encontrava sob o Compartimento 2, que totalizava uma área com cerca de $15 \mathrm{~m}^{2}$ (Unidades [159], [165], [171], [172], [184]). Por outro, quatro destas mesmas dez ânforas estão particularmente bem conservadas, faltando-lhes apenas parte do colo, o bordo e as asas, já que possuem fundo, a totalidade do corpo e a metade inferior do colo. Duas delas foram encontradas inteiras, estando as outras duas fracturadas in situ.

A classificação das ânforas itálicas de Monte Molião teve por base as tipologias de referência, mas deve chamar-se desde já a atenção para as dificuldades que sentimos no momento de integrar tipologicamente algumas peças, nomeadamente quando pretendemos distinguir as greco-itálicas das ânforas Dressel 1A mais arcaicas, de bordo curto e oblíquo. Neste caso, a utilização do modelo de Gateau (relação altura do bordo/ espessura máxima do mesmo $\leq 1,2$, Gateau 1990) possibilita incluir vários fragmentos no primeiro dos tipos, mas a opção pelos critérios de Molina Vidal, «[...] siempre que el ángulo formado entre la parte superior del labio y el eje de la pieza sea igual o superior a $45^{\circ}$ tendremos ánforas grecoitálicas» (Molina 1997: 42), diminui consideravelmente este número. A verdade é que a fronteira entre os bordos pendentes e triangulares, característicos das greco-itálicas e das Dressel 1A, é, como sabemos, muito ténue, sobretudo quando estamos perante uma fase evoluída da produção das primeiras, e num momento em que as segundas começaram a fabricar-se. Assim, e, por exemplo, alguns dos corpos inteiros, podem caber indistintamente em uma ou outra forma, ou ainda no que se convencionou designar por "formas de transição".
Esta dificuldade foi já sentida por outros investigadores, tal como A. Tchernia (1986: 309), que considerou ser grande a incerteza no momento de separar algumas greco-itálicas das Dressel 1A. Também Molina Vidal, que classifica os tipos C e E de Will como ânforas de transição, não deixa de chamar a atenção para o facto de que devemos ser «[...] muy escépticos a la hora de clasificar, sin más, como ánforas greco-itálicas estos contenedores de dificil adscripción» (Molina 1997: 40).

As ânforas itálicas de Monte Molião, concretamente as Dressel 1, apresentam algumas características morfológicas que importa aqui também destacar. A grande maioria mostra um perfil fusiforme alargado, lábios verticais, colo e asas longos, ombro estreito e curto, carena arredondada e fundo baixo, largo e maciço. Trata-se, portanto, e atendendo às sequências estratigráficas conhecidas, e sobretudo aos contextos de naufrágio já estudados, de peças que podem situar-se cronologicamente em torno aos meados da segunda metade do século II a.n.e., o que aliás concorda com a presença, ainda que numericamente muito menor, de ânforas greco-itálicas evoluídas nos mesmos contextos. Uma outra, porém, aparecida numa das U.E.s mais recentes do Sector A ([159]), é já distinta, com um corpo fusiforme estreito e fundo alto, maciço e tronco-cónico, cuja cronologia pode avançar para os finais do século II a.n.e. e mesmo para as duas primeiras décadas do seguinte.

Os dados dos naufrágios são particularmente úteis para discutir a cronologia e a sequência morfológica entre as diversas formas de ânforas itálicas, tendo sido nos de Colònia de Sant Jordi E e A que baseámos as observações cronológicas relativas aos exemplares que recolhemos no Monte Molião. No primeiro, as ânforas Dressel 1 são iguais às que recuperamos nos níveis republicanos mais antigos, tendo sido esta a forma que serviu de modelo para a cronologia de 125 a.n.e. avançada por Asensio na sua proposta de evolução tipológica das ânforas itálicas (2010: 30,36). No naufrágio de Colónia de Sant Jordi A, as ânforas fusiformes estreitas e altas estão já presentes, apontando o mesmo autor para uma cronologia mais lata de 125-50 a.n.e.

É longa a lista de sítios arqueológicos onde se documentou a presença de ânforas Dressel 1 de tipologia arcaica, associadas a outras de tipologia greco-itálica. Entre eles, parece importante destacar os dados provenientes de contextos mais ou menos seguros e/ ou de cronologia histórica "certificada". E se Cartago é uma referência incontornável entre os últimos, convém recordar que na cidade norte africana, destruída 


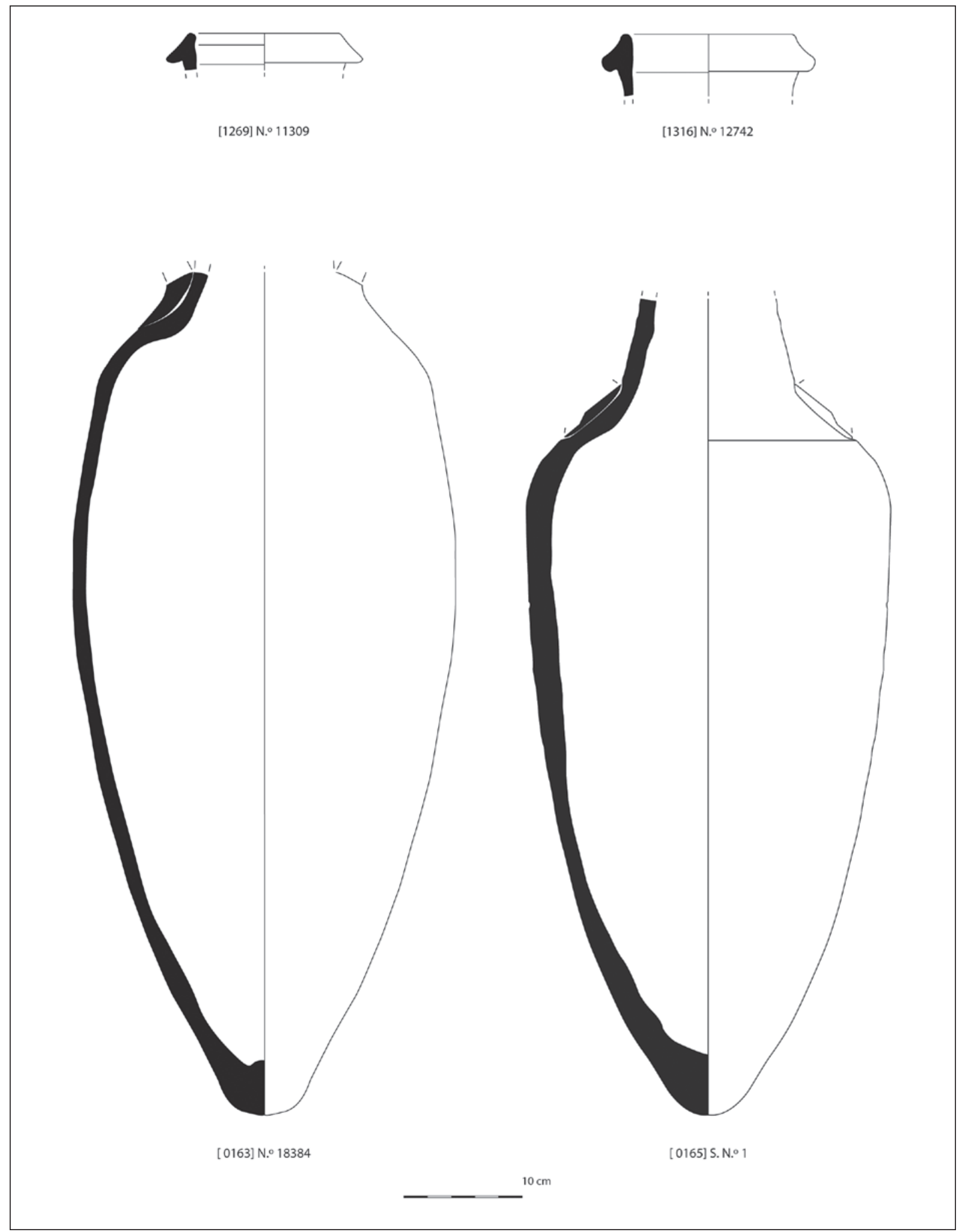

Figura 15. Ânforas de produção itálica dos contextos republicanos de Monte Molião: Greco-Itálicas (11309 e 12742) e GrecoItálicas / Dressel 1 (18384 e s. n. $\left.{ }^{\circ} 1\right)$.

ISSN: 1133-4525 ISSN-e: 2255-3924 


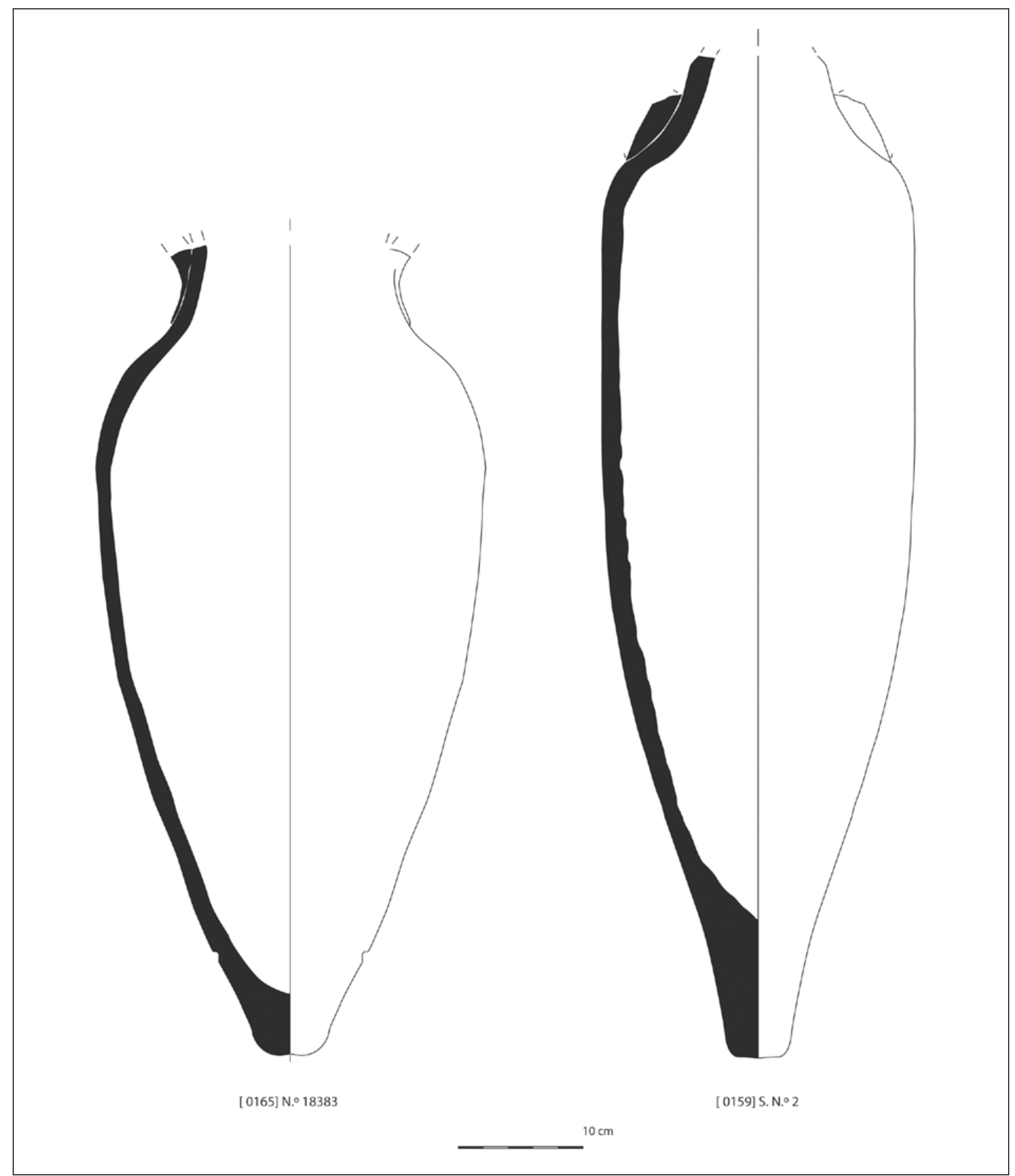

Figura 16. Ânforas de produção itálica dos contextos republicanos de Monte Molião: Greco-Itálicas / Dressel 1 (18383 e s. n. $\left.{ }^{\circ} 2\right)$. 


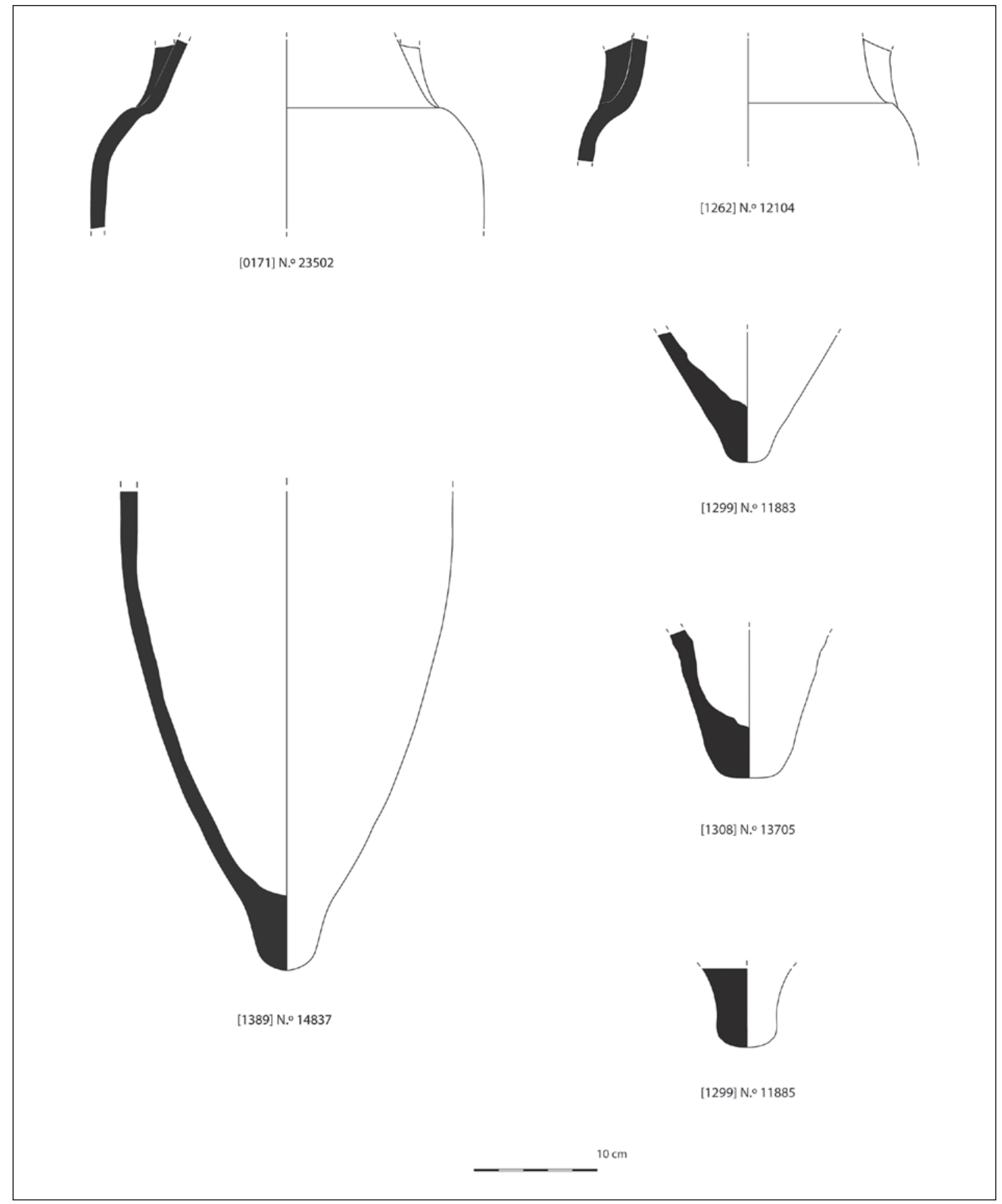

Figura 17. Ânforas de produção itálica dos contextos republicanos de Monte Molião: Greco-Itálicas / Dressel 1. 
114

ANA MARGARIDA ARRUDA / ELISA DE SOUSA

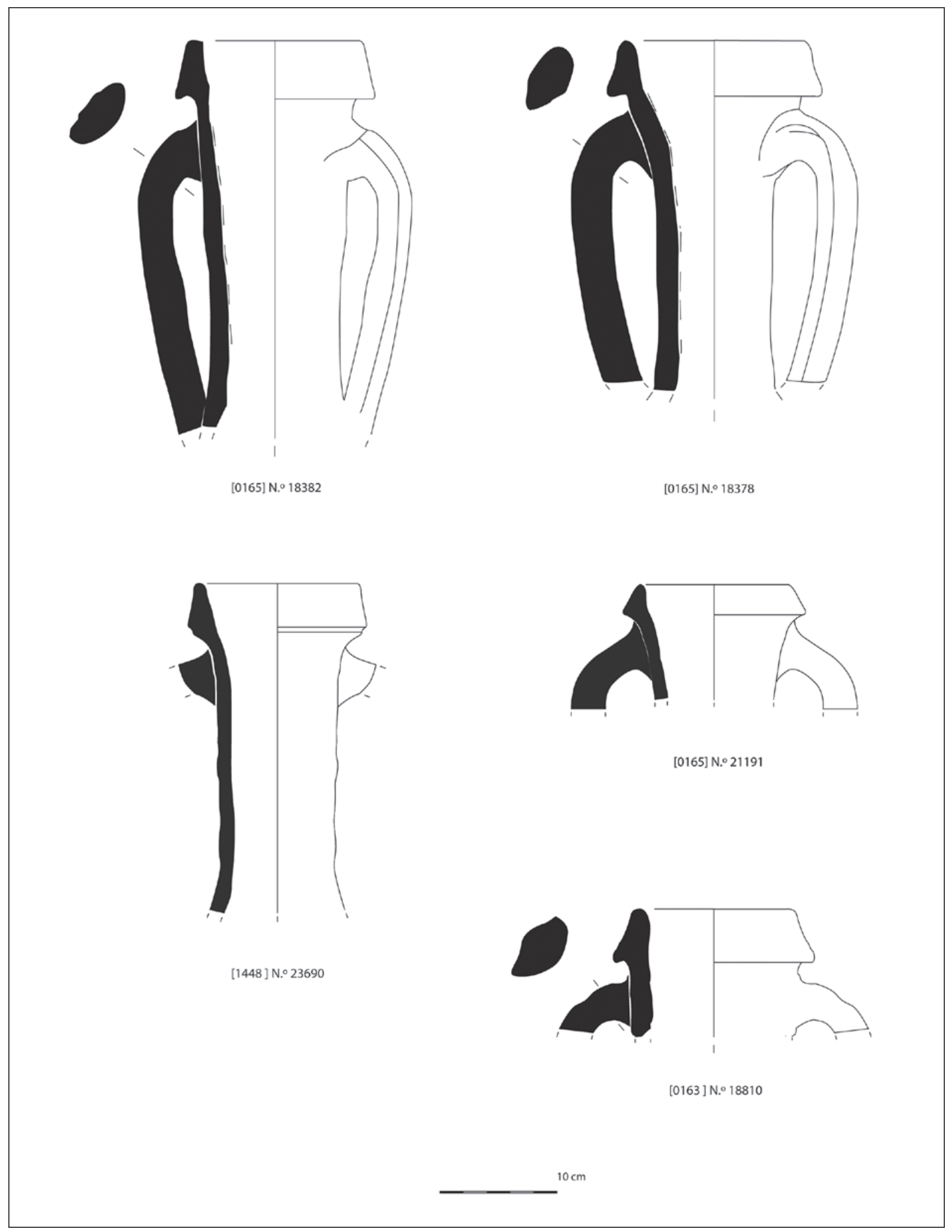

Figura 18. Ânforas de produção itálica dos contextos republicanos de Monte Molião: Dressel 1.

SPAL 22 (2013): 101-141

ISSN: 1133-4525 ISSN-e: 2255-3924

http://dx.doi.org/10.12795/spal.2013.i22.05 


$\begin{array}{cc}y & -d \\ -1 & 1 \\ 1 & 1 \\ 1 & 1 \\ - & 1\end{array}$




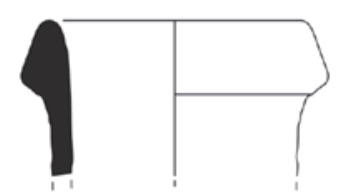

$[1299]$ N. ${ }^{\circ} 11876$

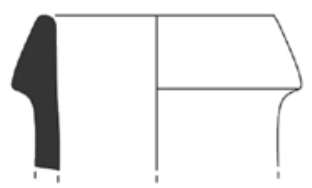

[1273] N.० 14474

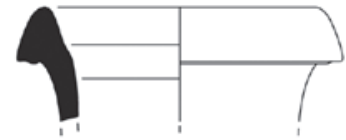

$[1269]$ N. .11310

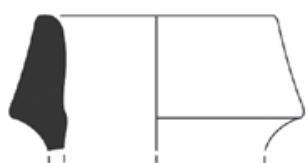

[1281] N.० 10997

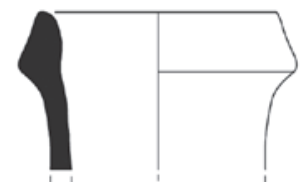

$[1304]$ N. .14767

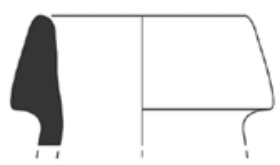

$[1260] N \cdot \circ 10894$

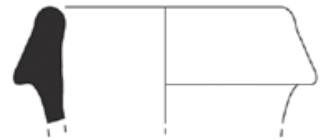

$[1299]$ N. 011877

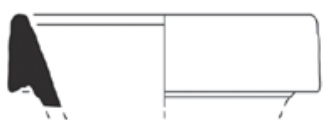

$[1269]$ N.॰ 11295

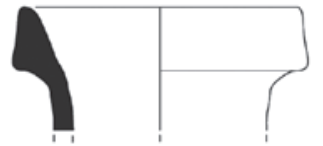

$[1261]$ N.0 10848 $10 \mathrm{~cm}$

Figura 20. Ânforas de produção itálica dos contextos republicanos de Monte Molião: Dressel 1. 
em 146 a.n.e., as ânforas greco-itálicas são exclusivas, ainda que relativamente raras (Wolf 1986, Morel 2004, Bechtold 2010). Nos acampamentos que rodearam Numância, vencida em 133 a.n.e., as duas formas coexistem, mas com uma clara dominância das Dressel 1 (Sanmartí 1985, 1992), o mesmo acontecendo em Valência, fundada em 138 a.n.e. (Ribera 1998, 2002). Também em Lisboa, que partilha com a cidade espanhola a data da fundação, bem como o fundador propriamente dito, as Dressel 1 dominam, coexistindo, no entanto, com as greco-itálicas, que se registam em quantidades ainda assim apreciáveis (Pimenta 2005). Nos sítios peninsulares, este momento, ainda do $3^{\circ}$ quartel do século II a.n.e., está também documentado por outros tipos anfóricos com distintas origens. É o caso das tripolitanas antigas e das Mañá C2, importadas do Norte de África, e das formas punicizantes da área do Estreito (tipo 9.1.1.1. e séries 12.0.0.0. e 7.0.0.0 de Ramón Torres), bem como por ânforas também itálicas, mas da costa Adriática ou do Sul.

As associações de materiais detectadas em Tarraco são também de considerar na análise cronológica do início da ocupação republicana de Monte Molião, ainda que nos pareça que a sequência crono-tipológica, de tão rígida e apertada, é, por vezes, difícil de sustentar (Díaz 2000). Com efeito, a separação em quartéis ensaiada para Tarragona parece excessivamente redutora e de difícil aplicação em outros sítios, em que a «longa duração» é um fenómeno que não se compadece com espartilhos desta natureza.

Para Sevilha, e para os momentos datados da $2^{\mathrm{a}}$ metade do século II a.n.e., os dados ainda escasseiam. No entanto, o contexto escavado na Rua Abades 41-43 forneceu alguns dados que importa não esquecer (García 2009). A datação foi avançada tendo presente o conjunto dos materiais, que reunia cerâmica campaniense, fundamentalmente de tipo A, ainda que as B calenas também já estivessem presentes, e ânforas itálicas (Dressel 1) e gadiritas (9.1.1.1.). Os materiais anfóricos itálicos recolhidos em Argote Molina, que foram inicialmente datados dos finais do II a.n.e., não se distanciam, em termos formais, dos de Abades 41-43, mas foram atribuídos ao $1^{\circ}$ quartel do século I a.n.e., tendo em consideração o contexto de recolha, que fornecia uma percentagem de Campaniense calena superior à de A. O critério usado pelo nosso colega de Sevilha parece aceitável, ainda que possa discutir-se a expressividade da amostra de base.

Vários sítios portugueses forneceram ânforas itálicas integráveis nos tipos greco-itálico e Dressel 1, mas, para além de Lisboa, apenas em Santarém e nas Mesas do Castelinho foi possível associá-las a níveis concretos. Para o primeiro, há dados publicados (Arruda e Almeida 1999, Bargão 2006), mas a primeira ocupação republicana não parece recuar para trás dos finais do século II/inícios do I a.n.e. Nas Mesas do Castelinho, torna-se ainda difícil aferir cronologias seguras para as diversas formas, até porque nos escapam, em grande parte, as associações contextuais dos materiais, anfóricos e não só (Parreira 2009).

No Algarve, no Forte de São Sebastião de Castro Marim, as importações itálicas são exclusivamente de tipo Dressel 1, recolhidas em níveis dos finais do século II a.n.e. (Arruda e Pereira 2008). Esta cronologia foi atribuída, tendo em consideração não só a morfologia das ânforas itálicas, mas também os dados dos restantes materiais recuperados. E, ainda que a campaniense seja exclusivamente A e a cerâmica de paredes finas esteja representada por formas I e II de Mayet, a ausência total de ânforas enquadráveis em tipos greco-itálicos obrigou a avançar a cronologia para a última década do século II. Situação similar ocorre no contexto republicano identificado nas imediações de Monte Molião, onde a forma Dressel 1 é maioritária entre as produções anfóricas itálicas (Sousa e Serra 2006).

A ocupação do Castelo da Lousa, onde se regista, exclusivamente, Dressel 1, não recua, considerando os dados disponíveis, para trás de meados do século I a.n.e. (Morais 2010).

Outros sítios portugueses ofereceram ânforas de tipo greco-itálico, Dressel 1A e as chamadas de transição, ainda que a sua cronologia não tenha sido possível de definir de forma exacta através de sequências estratigráficas. É, por exemplo, o caso de Mata Filhos, em Mértola (Luís 2003), Faro (Viegas 2011), Conímbriga (Alarcão 1976, Buraca 2005) e Chões de Alpompé (Fabião 1989, Diogo e Trindade 1998, Bargão 2006).

Também itálicos são dois bordos que foram classificados de Lamboglia 2, ambos, infelizmente recolhidos em contextos de revolvimento do Sector C. Por este motivo, não foram contabilizados, nem foram apreciados do ponto de vista percentual nos quadros sobre produtos consumidos, ou sobre a origem das importações. Contudo, a sua existência parece importante de assinalar. Apresentam perfil rectilíneo, de tendência rectangular, e um deles ostenta uma cartela na qual é visível uma marca impressa, que infelizmente não é possível ler, dado o estado de deterioração. Trata-se de contentores produzidos na costa adriática, muito possivelmente na Apúlia e na Calábria, a partir dos finais do século II a.n.e., quando os bordos eram de perfil triangular. Os com as características dos de Monte Molião 
são típicos da $1^{\mathrm{a}}$ metade do século I a.n.e. Estas observações cronológicas alicerçam-se sobretudo nos dados dos naufrágios, muito especialmente no da Colónia de San Jordi A e Escombreras 2 (Asensio 2010).

Ainda que raras no Ocidente, em geral, e em Portugal, em particular, surgem no Algarve, em Castro Marim, em contextos datados do terceiro quartel do século I a.n.e. (Arruda e Almeida 1998, Bargão 2006, Viegas 2011). O número e o estado de conservação obrigam a que se destaque os exemplares recolhidos no depósito de Mértola (Fabião 1987).

\subsection{As ânforas norte africanas}

No conjunto das ânforas de época republicana recuperadas em Monte Molião, contam-se 26 indivíduos que, recolhidos em contextos de ocupação, pudemos associar a produções do Norte de África (fig. 21 e 22). Correspondem a $11,06 \%$ do conjunto anfórico analisado. A sua origem concreta não é fácil de determinar com exactidão, uma vez que as pastas apresentam características que permitem englobá-las indistintamente no que Joan Ramón designou de Grupo Cartago/Tunes e Grupo Tripolitânia (Ramón 1995: 259-260).

Destas 26 ânforas, 19 integram-se no que habitualmente se denomina Mañá C2, e que correspondem, neste caso concreto, aos tipos 7.4.2.1., com bordos de menor complexidade, e 7.4.3.1. com bordos muito moldurados (Ramón 1995: 209-211). Segundo o autor da tipologia, ambos foram produzidos nos mesmos centros oleiros da área de Cartago/Tunes, estando a cronologia proposta centrada na primeira metade do século II a.n.e.

Em Monte Molião, os contextos de recolha destas ânforas indicam que a produção se prolongou pelo menos até ao início do último quartel do século II a.n.e., tal como já tinha sido documentado em Valência (Ribera e Marín 2003), Lixus (Bonet et al. 2005) e Tarragona (Díaz 2000). Cabe, contudo, assinalar, que, no Sector C, estas produções são consideravelmente mais abundantes no momento inicial da ocupação republicana (11 NMI) do que na fase 2 (5 NMI). No Sector A, ainda que os dados sejam mais escassos, importa referir que se recuperou um exemplar de perfil bastante completo numa das U.E.s que se depositaram sobre o pavimento [191], ou seja um dos primeiros.

Uma ânfora que indiscutivelmente cabe no tipo 7.3.1.1. foi também recolhida, concretamente no Sector A, mas infelizmente fora do seu contexto primário. De qualquer modo, e dada a importância deste achado, entendemos fazer-lhe aqui referência. Trata-se de uma forma que parece estar na transição entre as Mañá C1 e Mañá C2, que, tal como as primeiras, apresenta colo muito curto, mas o bordo já é moldurado e horizontal, assemelhando-se assim às segundas. Se uma origem na área de Cartago/Tunes não levanta grandes dúvidas, a cronologia proposta por Ramón Torres (1995: 207) parece ser de rever, com base nos dados de Monte Molião. Com efeito, e ainda que tenha sido recolhida em unidade estratigráfica de época romana alto-imperial, e que seja indiscutível que o sítio foi ocupado durante o século III a.n.e., não parece possível defender uma cronologia da Idade do Ferro para esta ânfora, uma vez que se trata de uma forma que não terá sido exportada para a Península Ibérica em momento anterior à época romana. Por outro lado, a própria proposta de Ramón Torres - final do III a.n.e. - é feita com reservas (Ramón 1995: 207).

Quatro outros bordos (4 MNI), também com pastas características da zona norte africana (Tripolitânia, Bizacena, Cartago/Tunes), englobam-se na forma que se costuma designar por Tripolitana Antiga (fig. 22). Três foram recuperados no Sector A, concretamente nas U.E.s [165] e [184], unidades que forneceram também ânforas itálicas de tipo Dressel 1 e Mañá C2 oriundas do Norte de África (Cartago/Tunes). Lembre-se que Joan Ramón já referiu que «...la dispersión occidental de las tripolitanas antiguas antes de la destrucción de Cartago parece muy escasa [...] se intensifica sin duda tras el citado acontecimiento histórico...» (Ramón 2008: 69). Com datas da segunda metade do século II a.n.e., encontram-se os exemplares de Valência (Ribera e Marín 2003) e dos acampamentos romanos de Numância (Principal 2000), assim como os recolhidos em alguns naufrágios, onde estão, tal como em Monte Molião, acompanhados por quantidades significativas de contentores vinários produzidos na costa tirrénica da Itália.

Em Portugal, as ânforas norte africanas não são abundantes, conhecendo-se apenas três exemplares de Mañá C2 (7.4.1.1.) recuperados em Santarém (Arruda e Almeida 1998, Bargão 2006), bem como os de Castro Marim (Arruda et al. 2006, Viegas 2011), Faro (Viegas 2011) e Cerro do Cavaco (Bargão 2006). Recordamos que nas escavações concretizadas pela empresa $\mathrm{Pa}$ limpsesto na área envolvente do Monte Molião já se tinha documentado quer a forma quer a produção (Sousa e Serra 2006).

Em relação às Tripolitanas Antigas, o tipo foi identificado na Lomba do Canho (Fabião 1989), em Santarém, em níveis da segunda metade do século I a.n.e. 


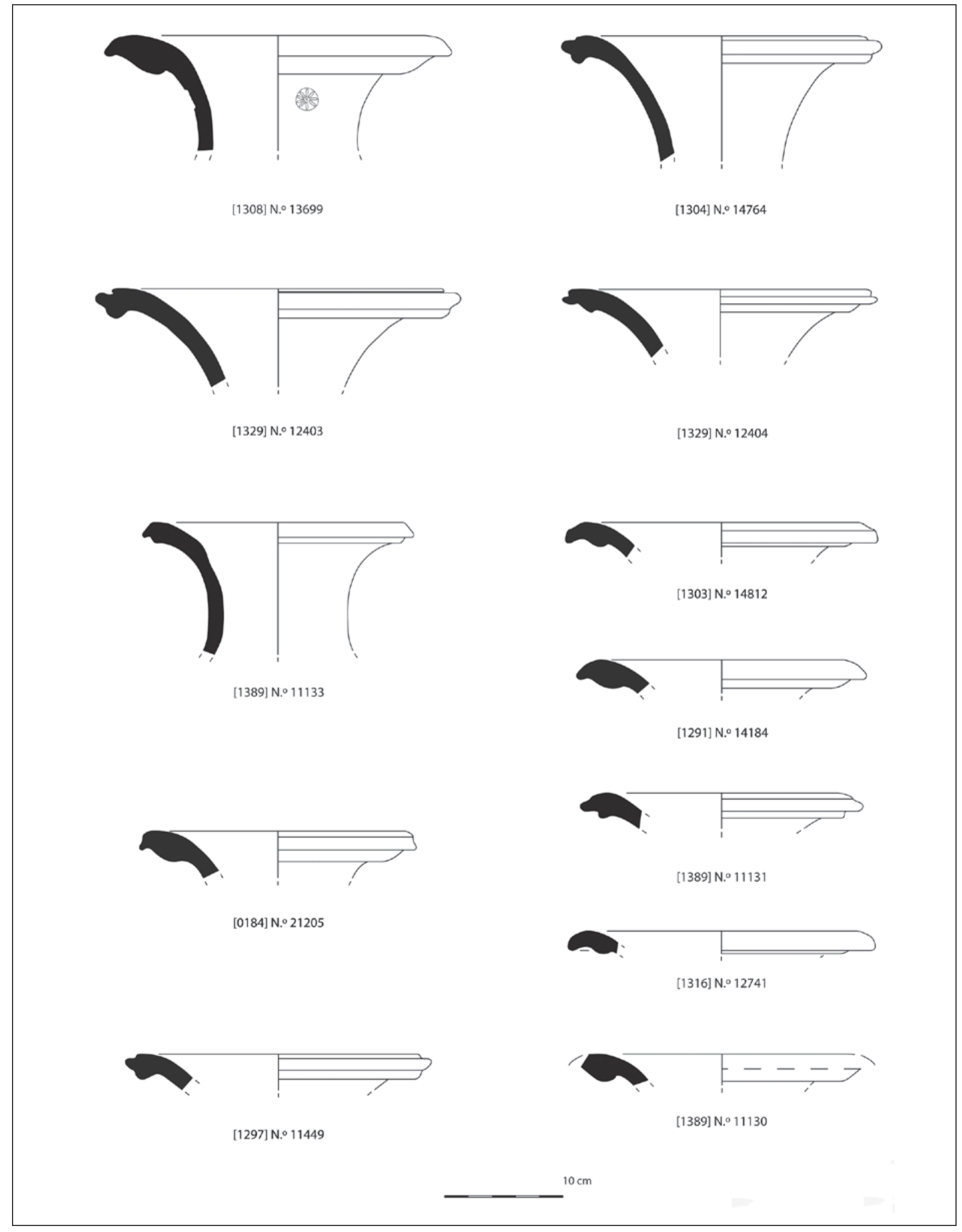

Figura 21. Ânforas de produção africana dos contextos republicanos de Monte Molião: Mañá C2. 

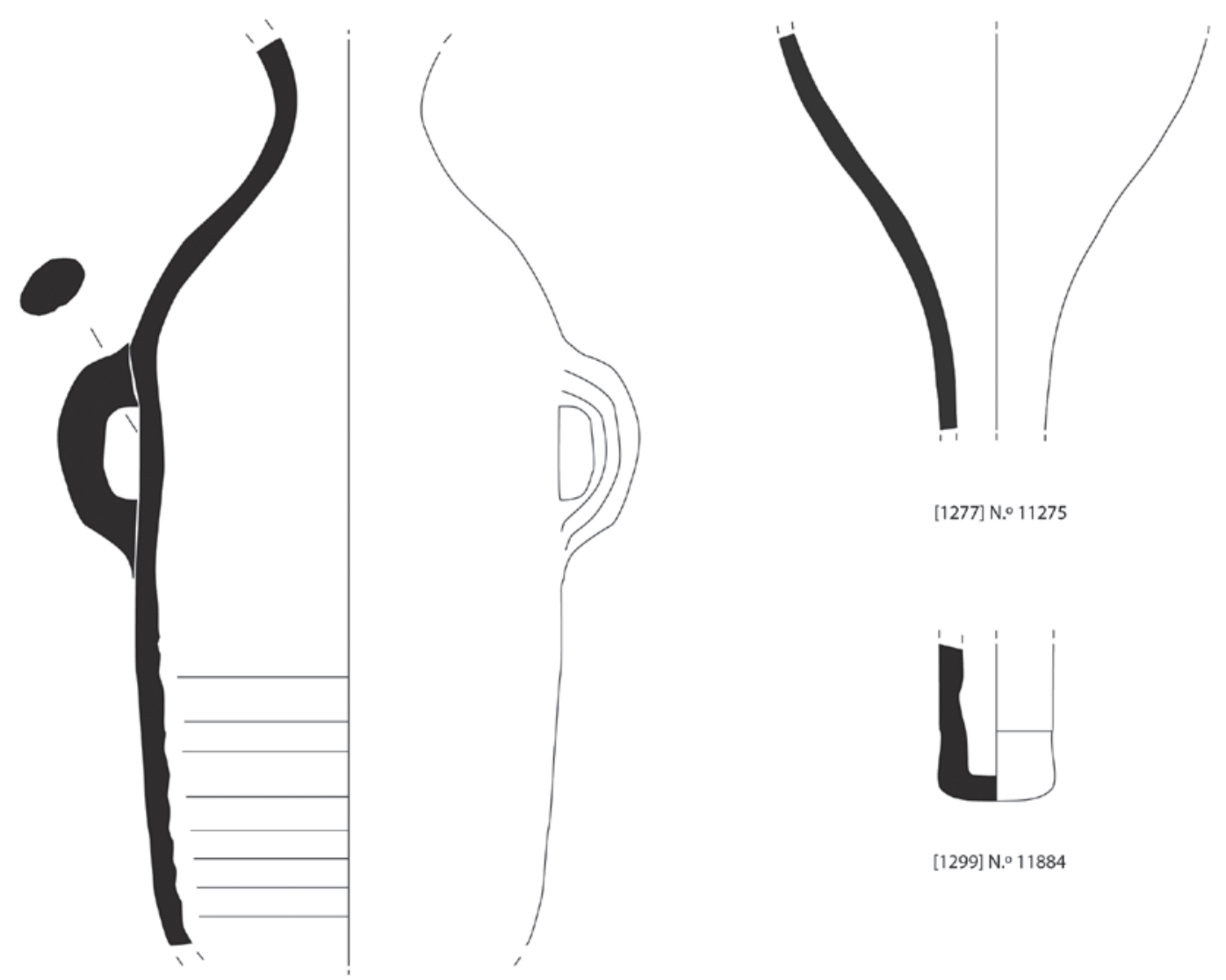

[1277] N. 011275

$[0184]$ N..$^{\circ} 18665$
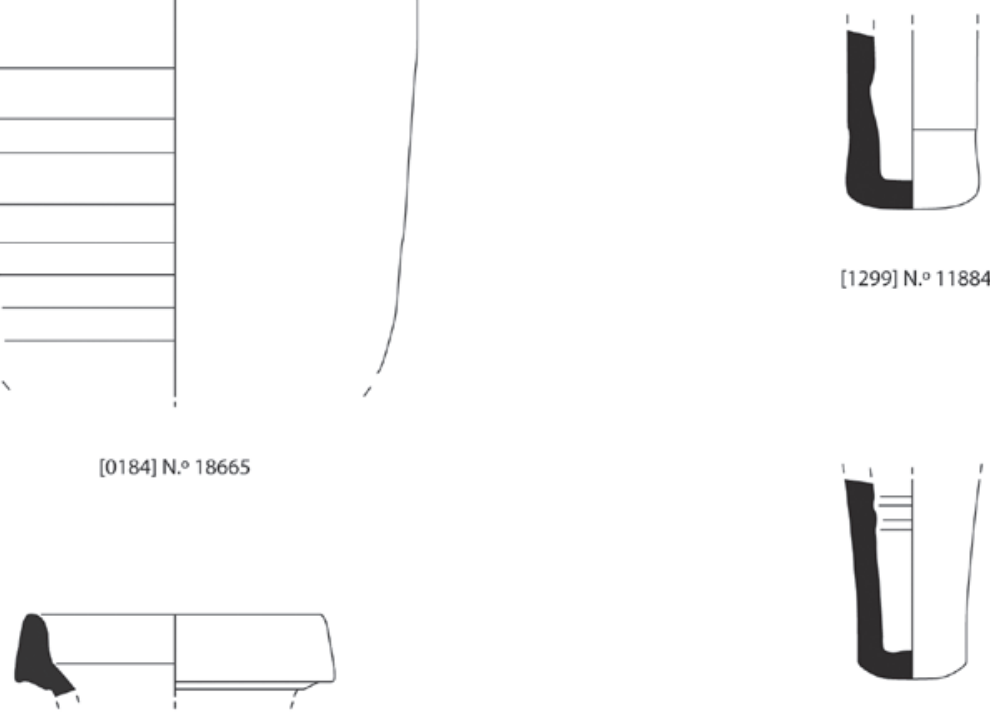

[1299] N.0 11884

$[1389]$ N.0 11129

$[0184]$ N.021211
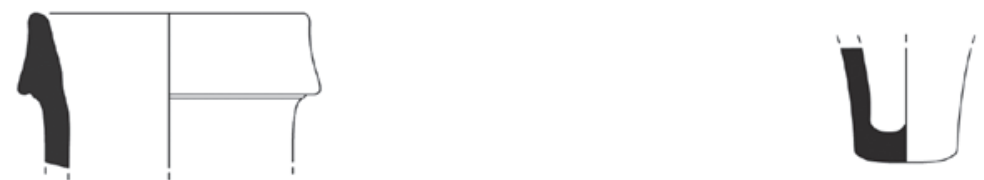

[0165] N.० 18743

$[1389]$ N. 011133

$10 \mathrm{~cm}$

Figura 22. Ânforas de produção africana dos contextos republicanos de Monte Molião: formas indeterminadas (Mañá C2 ?) (18665, 11275, 11884, 11129 e 11133) e Tripolitanas Antigas (21211 e 18743). 
(Almeida e Arruda 2005, Bargão 2006), em Lisboa, em contextos datados de 140-130 a.n.e. (Pimenta 2005), nas Mesas do Castelinho (Parreira 2009), em Castro Marim (Viegas 2011) e também na área envolvente ao Monte Molião (Sousa e Serra 2006). Entre os materiais de superfície de Chões de Alpompé poderão também constar exemplares desta morfologia (Pimenta 2005).

\subsection{As ânforas de produção gaditana}

Em contextos primários de ocupação recolheu-se, em Monte Molião, um conjunto de ânforas que foram produzidas no sul do território peninsular, mais concretamente na área da baía de Cádis, representando $46,81 \%$ do total de contentores (fig. 23-27). Em termos morfológicos, a diversidade é considerável.

$\mathrm{O}$ registo formal mostra um absoluto predomínio das ânforas Mañá C2 (42 NMI), tendência que, aliás, já se observava nas importações norte africanas. Seguem-se as ânforas tipo Castro Marim 1 (27 NMI), forma que só há pouco tempo foi devidamente individualizada (Arruda et al. 2006, Arruda e Bargão no prelo). Os outros tipos estão escassamente representados, nunca atingindo a dezena. Entre estes, o mais representativo corresponde ao D de Pellicer (9 NMI), seguindo-se as Dressel 1 (7 NMI), as Mañá Pascual A4 (5 NMI), as 9.1.1.1. (4 NMI) e as Carmona/8.2.1.1. (4 NMI). Refira-se ainda que a grande maioria dos fragmentos que não pudemos classificar (12 NMI) se refere a asas e fundos, que podem indistintamente pertencer a qualquer das formas. Um bordo que entrou nesta categoria pode ainda corresponder a uma ânfora oleária, produzida na área da baía de Cádis, talvez inspirada nos modelos das Tripolitanas Antigas.

A análise estratigráfica permitiu outras abordagens, havendo dados que importa ainda acrescentar, tendo em consideração a diacronia republicana. A ausência de produções gaditanas de Dressel 1 no momento inicial da ocupação republicana é um desses elementos, até porque permite discutir a sequência cronológica republicana do sítio. Outro facto que importa destacar é o aumento exponencial dos tipos Mañá C2 e Castro Marim 1 entre os níveis mais antigos e os mais recentes, que passam de $6 \mathrm{NMI}$ e 1 NMI, respectivamente, nos correspondentes à primeira fase, para 29 NMI e 16 NMI, nos da segunda.

Mais importante parece ser o aumento das importações gaditanas ao longo da ocupação. De facto, para os $24,14 \%$ registados para os primeiros níveis, calcularam-se $56,20 \%$ para os mais tardios.
As ânforas Mañá C2 produzidas na baía de Cádis são, como já referimos, maioritárias dentro desta produção, quer nos níveis correspondentes às primeiras ocupações romanas quer nos mais recentes (fig. 23 e 24). Trata-se, neste caso, de exemplares que se integram nos tipos 7.4.3.2.e 7.4.3.3. de Ramón Torres. Tanto os grupos específicos como os números de que dispomos não destoam do panorama do sul peninsular, sendo as ânforas deste tipo sempre muito numerosas e percentualmente significativas nos conjuntos das importações gaditanas de época republicana. Para Portugal, o tipo, cuja dispersão é vasta, destaca-se nos conjuntos de Santarém (Arruda e Almeida 1998), Lisboa (Pimenta 2005) e Mesas do Castelinho (Parreira 2009). No Algarve, o caso de Faro é paradigmático, com um número de Mañá C2 de produção gaditana muito significativo, apenas ultrapassado pelo das Castro Marim 1 (Viegas 2011: 204). A situação inverte-se em Castro Marim, sítio em que as primeiras, maioritárias, excedem ligeiramente as segundas (Arruda et al. 2006, Viegas 2011: 496). Note-se, contudo, que, segundo os autores que estudaram aqueles espólios, os contextos de recolha nos sítios algarvios são, para Faro, desconhecidos, e consideravelmente tardios (50-30 a.n.e.), para Castro Marim. Apenas no Forte de São Sebastião, também em Castro Marim, estes contentores foram encontrados associados em contextos primários, contextos esses datados dos finais do século II a.n.e. (Arruda e Pereira 2008). Apesar de se tratar de uma amostra reduzida (15 exemplares), também aqui os tipos são numericamente equivalentes, representando a maioria das importações da província da Ulterior. Lembre-se ainda que a forma já tinha sido reconhecida em Monte Molião, concretamente nas escavações concretizadas na área envolvente (Sousa e Serra 2006).

De qualquer modo, no Algarve os dois tipos perfazem, em conjunto, 71\% no Castelo de Castro Marim e 95\% em Faro (Viegas 2011), dados confirmados pelos dados recuperados no Forte de São Sebastião (Arruda e Pereira 2008), onde as duas ânforas, sendo numericamente equivalentes, representam a maioria das importações da província da Ulterior.

Tal como se pode constatar pelo presente estudo, a mesma situação verifica-se também em Monte Molião, onde as ânforas Mañá C2 e Castro Marim 1 correspondem a $62,73 \%$ das importações da área de Cádis.

Sobre as ânforas Castro Marim 1, deve ainda acrescentar-se que se trata de uma forma com bordo de pequeno diâmetro, inferior a $11 \mathrm{~cm}$, sem espessamento ou com um leve engrossamento na extremidade, com ombro horizontal, constituindo no seu conjunto uma 


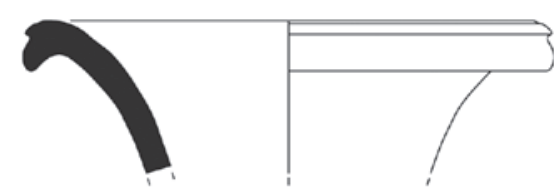

[1277] N.॰ 11276

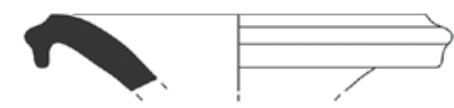

[1260] N. ${ }^{\circ} 10896$

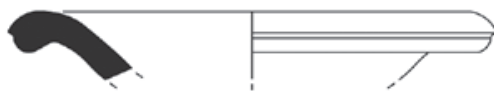

[1297] N.० 11451

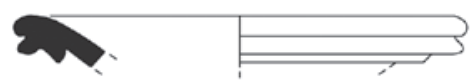

$[1297]$ N. ${ }^{\circ} 11450$

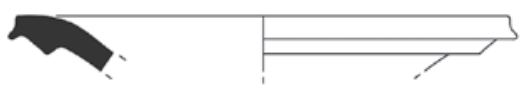

$[0165]$ N. 018747

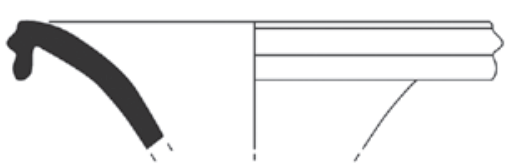

[1277] N.・11277

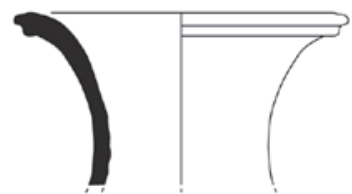

[1299] N.11882

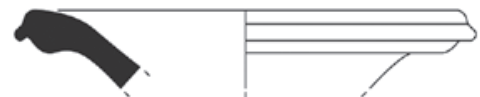

[1281] N.o 10992

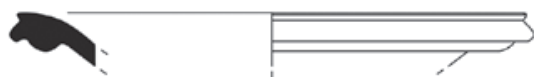

$[1268]$ N.o 10845

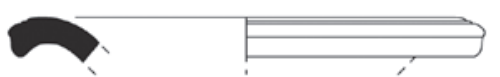

[1262] N.0 12098

$10 \mathrm{~cm}$

Figura 23. Ânforas de produção gaditana dos contextos republicanos de Monte Molião: Mañá C2. 


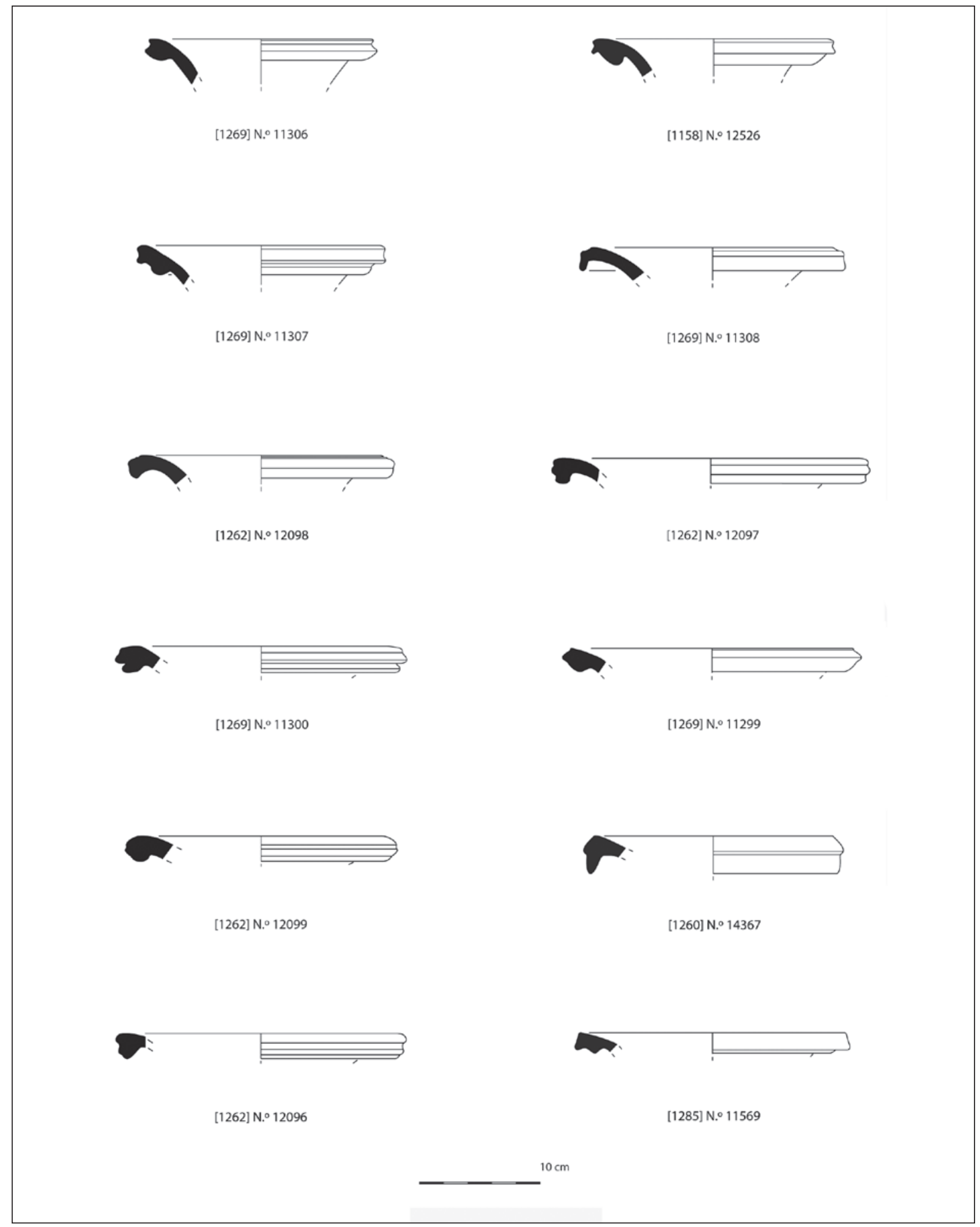

Figura 24. Ânforas de produção gaditana dos contextos republicanos de Monte Molião: Mañá C2. 
espécie de disco (fig. 25). O corpo é cilíndrico e estreito, de largura igual ou inferior a $26 \mathrm{~cm}$, de paredes rectas, sendo a ligação entre o corpo e o bordo efectuada através de uma carena, que forma um ângulo próximo do $90^{\circ}$ (Bargão e Arruda no prelo). Em termos formais, o tipo parece inspirar-se na forma $D$ de Pellicer, mais exactamente na variante D4, sendo assim designada por muitos dos nossos colegas espanhóis. Corresponde a um contentor tardo-púnico, cuja produção não deverá ter-se iniciado num momento anterior aos finais do século III a.n.e., e que, a avaliar pelos dados dos centros de consumo, se manteve até à segunda metade do século I a.n.e. Para a última cronologia valem, sobretudo, os dados portugueses, concretamente os de Castro Marim, onde as ânforas deste tipo ocorrem em grande número, num contexto datado de 50/30 a.n.e. (Arruda et al. 2006, Viegas 2011, Bargão e Arruda no prelo). Também em Castro Marim, mas no forte de São Sebastião, sítio onde a ocupação foi datada do último quartel do século II a.n.e., foram recolhidos estes contentores (Arruda e Pereira 2008), assim como na área envolvente de Monte Molião (Sousa e Serra 2006). Relativamente à datação do início da produção ela é mais difícil de avaliar, até porque tem quase exclusivamente por base os dados recuperados por Ferrer Albelda em trabalhos de prospecção concretizados na área de Baesipo, especificamente em Manzanete Bajo e Benitos del Lomo, onde o conjunto do espólio permitiu ao colega de Sevilha propor uma cronologia entre finais do século III e inícios do II a.n.e. (Ferrer 2007: 295-296).

Os dados de Monte Molião não trazem elementos que alterem o que, de momento, conhecemos para a questão da cronologia da produção e distribuição desta ânfora. Ela está presente em ambos os momentos de ocupação republicana, podendo-se no entanto acrescentar que o seu número é mais elevado nos níveis mais avançados.

Este tipo anfórico tem uma distribuição relativamente ampla no território actualmente português. Para além dos sítios algarvios, como Castro Marim (Castelo e Forte de São Sebastião), Faro e Monte Molião, foi reconhecido no vale do Tejo, concretamente em Santarém (Bargão no prelo) e também no Porto do Sabugueiro (Pimenta e Mendes 2008: 182, fig. 11, n 20-21).

No Sul de Espanha, e para além dos sítios da área de Baesipo, já citados, devem referir-se os exemplares de Niebla (Campos et al. 2007: 273, fig. 277, Belén 2007: fig. 241 e 247) e ainda os dos centros produtores de Las Redes (Frutos et al. 1988: fig. 2) e de Pajar de Artillo (Luzón 1973).
As ânforas de tipo D de Pellicer correspondem a um contentor que surge ainda durante a Idade do Ferro, concretamente durante o século IV a.n.e., no sul do território peninsular. Individualizadas pela primeira vez entre os materiais recuperados no Cerro Macareno (Pellicer 1978), correspondem a recipientes de perfil cilíndrico, com um bordo reentrante, cujo engrossamento interno é variável, e que pode ainda ocorrer no lado externo (fig. 26). O tipo equivale à forma $\mathrm{C} 1$ de Muñoz Vicente (1985), Cádis C1 de García Vargas (1998) e ainda ao tipo 4.2.2.5. de R. Torres (1995). O conteúdo destes recipientes é ainda discutível, tendo sido já proposto o transporte de azeite ou vinho. No entanto, para as produções da baía de Cádis, um conteúdo piscícola é aceite por grande parte dos investigadores (García 1998).

Apesar da sua origem pré-romana, a sua comercialização estende-se até ao período republicano. Com efeito, no território algarvio, ânforas com esta morfologia foram recuperadas em níveis dessa cronologia, quer em Faro (Viegas 2011) quer em Castro Marim (Arruda et. al. 2006, Viegas 2011). Na costa ocidental atlântica, concretamente em Santarém (Arruda 1999-2000) e em Lisboa (Pimenta 2005), este tipo surge em níveis do período republicano, ainda que, em ambos os casos, as características macroscópicas das pastas apontem para produções locais. No interior, contamos com os dados das Mesas do Castelinho, onde também existem ânforas desta categoria formal em níveis republicanos (Parreira 2009).

No Monte Molião, em contextos conservados do período republicano, estas ânforas estão representadas por nove indivíduos. Do mesmo sítio, mas da sua área envolvente, já existiam dados que comprovavam a sua permanência em níveis correspondentes à ocupação romana (Sousa e Serra 2006).

As ânforas conhecidas por Mañá-Pascual A4 integram-se nas séries 11 e 12 de R. Torres e correspondem a um dos contentores mais emblemáticos do Extremo Ocidente. A sua produção, que se inicia em meados do $1^{\circ}$ milénio a.n.e., possivelmente em torno aos momentos finais do século VI a.n.e., perdura, nas suas variantes evolucionadas, até ao período tardo-republicano. São contentores de bordo reentrante, com engrossamento externo e/ou interno, com diâmetros reduzidos, sem colo, e de ombros altos e arredondados, cuja separação do resto do corpo é efectuada mediante uma carena mais ou menos acentuada. O seu conteúdo piscícola é hoje inegável. A evolução desta forma, a partir do séc. III a.n.e., está marcada pela perda do espessamento do bordo e por uma orientação mais vertical das paredes, como é visível nas ânforas integradas na série 12 


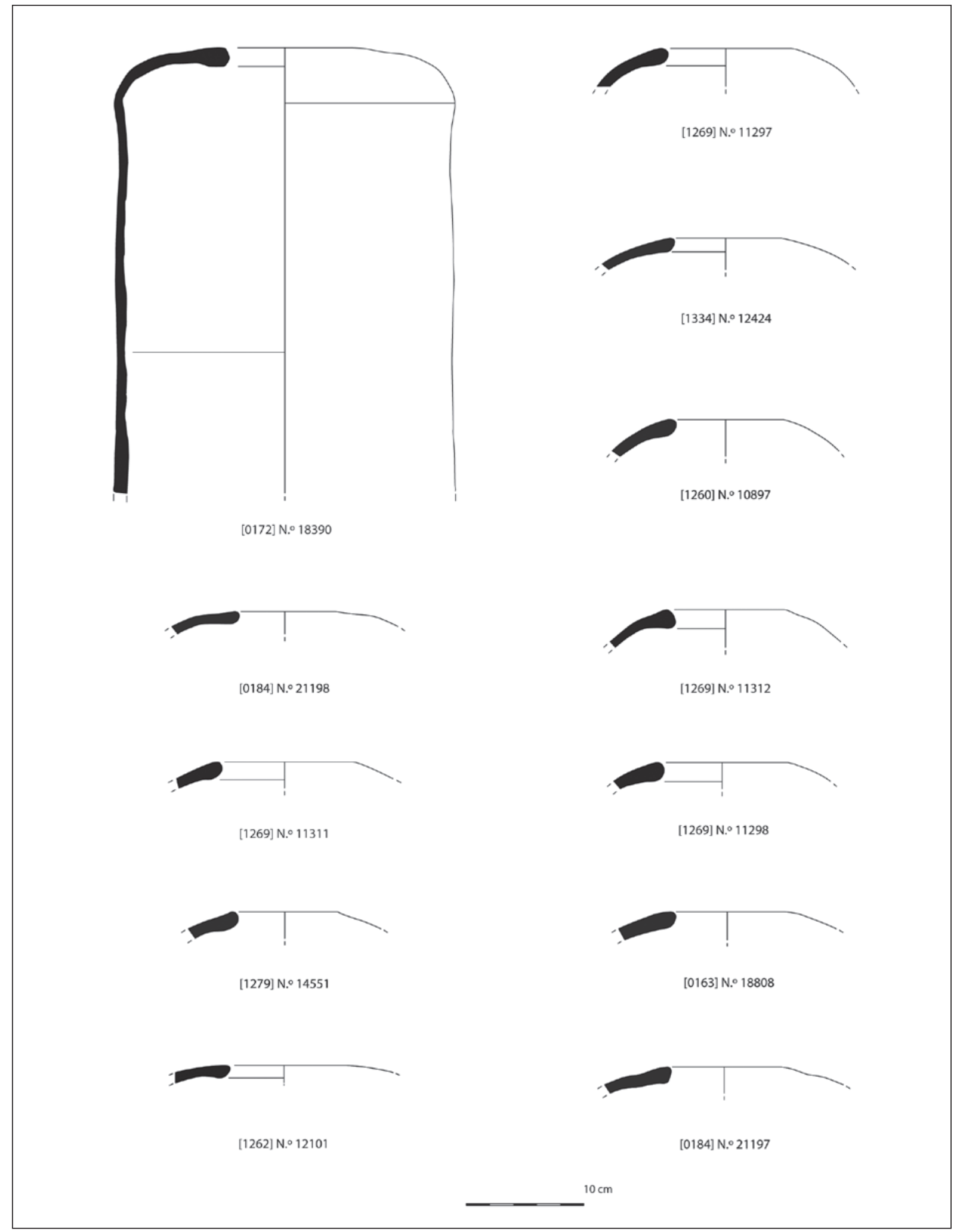

Figura 25. Ânforas de produção gaditana dos contextos republicanos de Monte Molião: Castro Marim 1.

ISSN: 1133-4525 ISSN-e: 2255-3924 


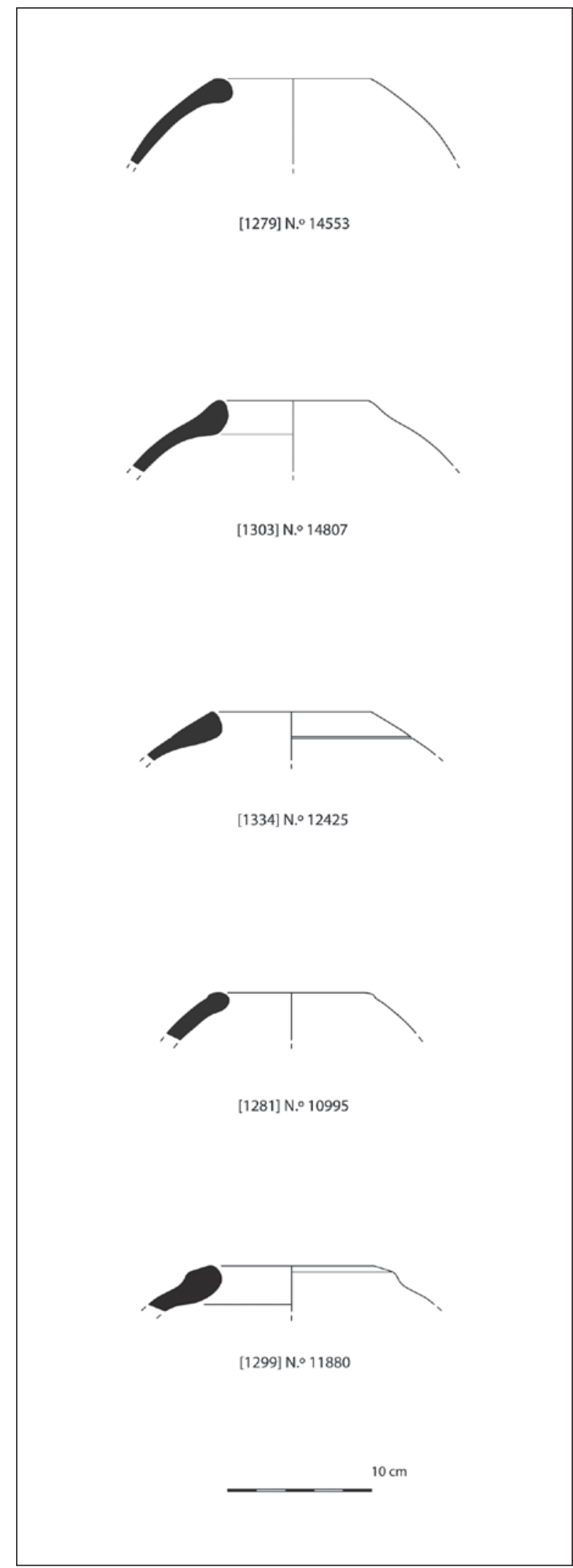

Figura 26. Ânforas de produção gaditana dos contextos republicanos de Monte Molião: D de Pellicer.

de Ramón Torres, e cuja cronologia parece estar balizada entre finais do séc. III a.n.e., podendo chegar até um momento tardio da fase republicana. Os centros produtores são numerosos na baía gaditana, destacando-se os de Torre Alta (Perdigones e Muñoz 1988), Pery Junquera (Gonzalez et al. 2000) e Villa Maruja (Bernal et al. 2003), entre os que atingem cronologias mais tardias.

Os exemplares que surgem nos níveis republicanos de Monte Molião, de produção gaditana (5 NMI), exibem características já tardias no quadro da evolução da forma, integrando-se na série 12.1.1.1./2. de Ramón Torres. A perduração deste tipo anfórico em contextos mais tardios já tinha sido evidenciada em outros sítios algarvios, como, por exemplo, Castro Marim (Arruda et al. 2006), onde um total de 58 exemplares integráveis nos tipos 12.1.1.1., 12.1.1.2 e 12.1.1.1./2. foi exumado em níveis datados em torno a 50-30 a.n.e. (Santos 2009). Também em Lisboa estas formas mais tardias surgem igualmente associadas a contextos republicanos (Pimenta 2005). Deve, contudo, referir-se que correspondem a produções locais da área lisboeta, que podem não ter uma equivalência exacta nos protótipos mais meridionais.

Outra forma presente entre as produções anfóricas gaditanas em Monte Molião é o tipo 9.1.1.1. de Ramón Torres (fig. 27). Esta é uma ânfora que, muito provavelmente, se inspira no tipo 8.2.1.1., que o precede (Ramón 1995). Trata-se de contentores cilíndricos, de dimensão consideravelmente reduzida, com bordo vertical e espessado no lado interno. Cabe no tipo E2 de Cádis (García 1998), E2 de Muñoz Vicente (1985) e CC.NN de Sanmartí (1985).

Cronologicamente, o início da sua produção é recuado para os finais do século III a.n.e., perdurando durante toda a centúria seguinte e atingindo os inícios do século I a.n.e.

O seu fabrico em centros produtores da baía de Cádis está bem atestado em San Fernando e Pery Junquera, sendo admitido, quer pela sua área primária de produção quer pela associação a algumas cartelas que exibem temática marinha em exemplares de Torre Alta, um conteúdo piscícola (García 1998).

Em contextos coevos aos identificados em Monte Molião, a sua presença ocorre nos acampamentos numantinos (Sanmartí 1985), onde foi pela primeira vez 


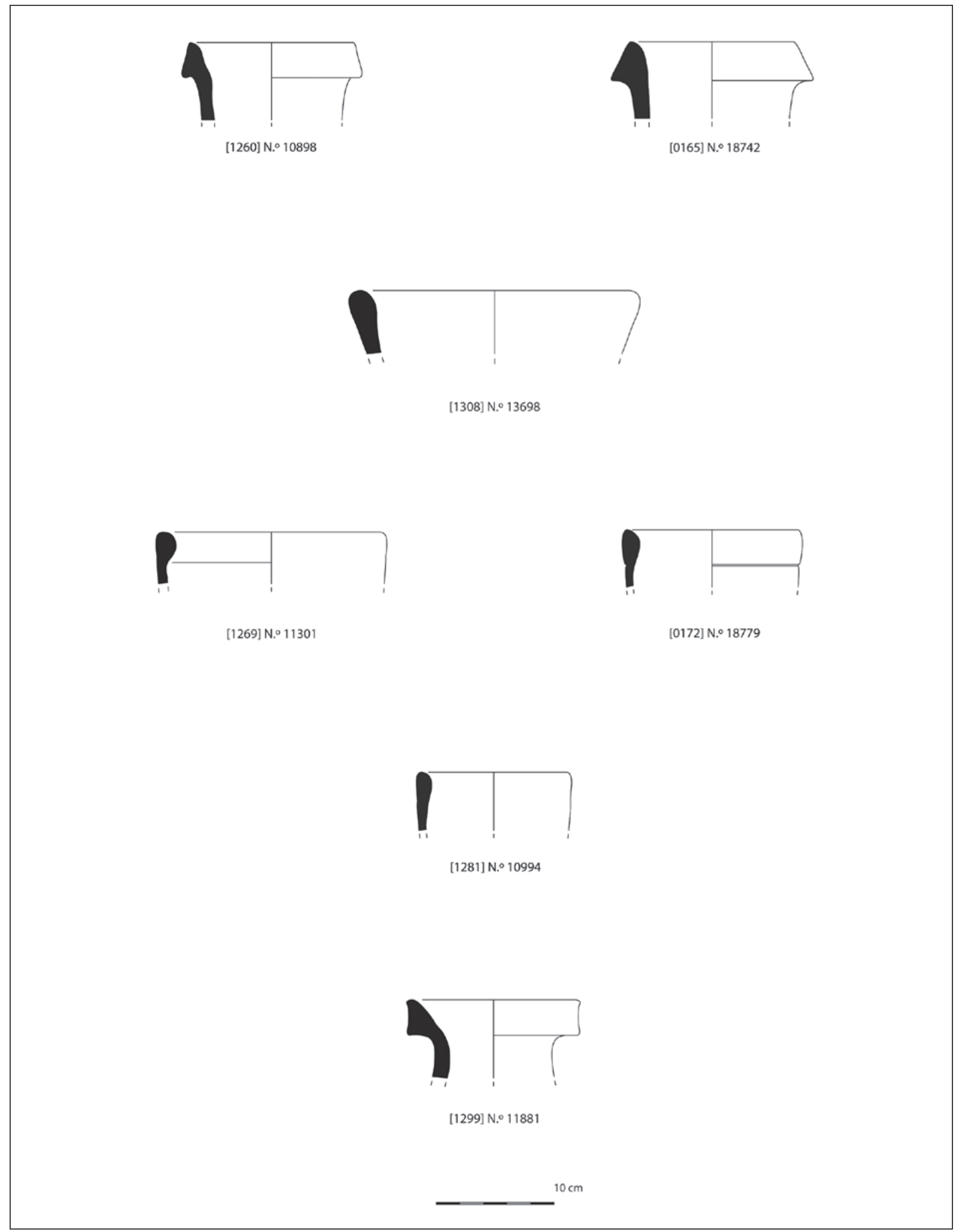

Figura 27. Ânforas de produção gaditana dos contextos republicanos de Monte Molião: Dressel 1 (10898 e 18742), Carmona / 8.2.1.1. (13698), 9.1.1.1. (11301, 18779 e 10994) e Tripolitana Antiga (11881).

ISSN: $1133-4525$ ISSN-e: 2255-3924 
individualizada, Valência (Ribera e Marín 2003), Lisboa (Pimenta 2005) e Pajar de Artillo (García 1998). Exemplares integráveis no tipo 9.1.1.1. foram também recuperados na área envolvente a Monte Molião, num contexto de idêntica cronologia (Sousa e Serra 2006), assim como nas Mesas do Castelinho (Parreira 2009). Em contextos mais tardios, este tipo surge também em Castro Marim (Arruda et al. 2006), Faro (Viegas 2011), Santarém (Arruda et al. 2005) e Chões de Alpompé (Diogo 1993).

A imitação sud-hispânica de modelos anfóricos itálicos foi relativamente frequente, tendo sido registada quer para as ânforas greco-itálicas quer para as Dressel 1, em Cádis, Algeciras e Málaga (García 1998, Bernal et al. 2003). A distribuição desta última forma produzida na área do Estreito está ainda em grande parte por fazer, mas sabe-se que as Dressel 1 A gaditanas estão presentes em boa parte do Mediterrâneo, como é o caso de Tharros, Roma ou Delos (García e Bernal 2008).

A sua presença no actual território português em contextos de época republicana não é infrequente, ainda que os exemplares sejam quase sempre pouco representativos. Em Lisboa, e sem contexto conhecido, foi documentada (Pimenta 2005), o mesmo se passando em Santarém, onde apenas um dos quatro fragmentos recolhidos, foi encontrado em nível conservado, datado da $2^{\mathrm{a}}$ metade do século I a.n.e. - associado a Haltern 70 e Classe 67 - (Arruda et al. 2005). Nas Mesas do Castelinho, Almodôvar, o número de fragmentos é maior, mas os dados escasseiam sobre a sua cronologia concreta (Parreira 2009).

Em Monte Molião, foi reconhecida a existência destas ânforas com origem na área do Estreito, que, contudo, representam apenas 6,36\% das importações gaditanas (fig. 27).

As ânforas de tipo Carmona, ou tipo 8.2.1.1. de Ramón Torres, correspondem a contentores de perfil tendencialmente recto, de corpo cilíndrico, com bordos de amplo diâmetro, com terminação genericamente arredondada, embora, por vezes, apresentem uma inclinação ligeiramente esvasada. Com alguma frequência, o bordo encontra-se separado do resto do corpo mediante uma ou várias caneluras. A evolução das características formais deste tipo anfórico teria originado, como já se referiu anteriormente, o aparecimento das ânforas de tipo 9.1.1.1. (Ramón 1995).

$\mathrm{O}$ início da sua produção remonta ainda à fase pré-romana, especificamente ao século IV a.n.e., quer na campiña gaditana quer na área de Cádis (Ramón 1995). No entanto, a revisão e análise dos dados de alguns centros produtores, concretamente Torre Alta, permitiram propor recentemente que estes contentores continuaram a ser fabricados na área gaditana até ao último quartel do século II a.n.e., quando se tornaram mais compridos e mais estreitos (Sáez 2008). Contudo, não pudemos deixar de nos surpreender com o facto de os contextos bem datados em torno ao último terço do século II a.n.e., como é o caso de Valência (Ribera e Marín 2003), Lisboa (Pimenta 2005) e acampamentos numantinos (Principal 2000), estas ânforas se encontrarem ausentes, estando, no entanto, documentadas as do tipo 9.1.1.1.

Também neste caso, a adscrição de um conteúdo é problemática, tendo sido avançada a possibilidade de servirem para o transporte de produtos agrícolas, como vinho ou azeite, no caso concreto das produções da Campiña (Carretero 2004). Porém, e tal como ocorre para o tipo D de Pellicer, assume-se que as produções da baía de Cádis envasariam preparados piscícolas (Carretero 2004).

No território actualmente português, o aparecimento destes contentores em níveis republicanos só se registou, até ao momento, nas Mesas do Castelinho (Parreira 2009) e, agora, em Monte Molião (fig. 27). Devemos, ainda assim, realçar que a existência, neste sítio algarvio, de materiais residuais pré-romanos nos contextos arqueológicos do século II e I a.n.e. permite levantar a questão de a presença das ânforas de tipo Carmona / 8.1.1.2. de R. Torres poder também relacionar-se com fenómenos dessa natureza. Contudo, e considerando a cronologia recentemente avançada por Sáez (2008), não pudemos deixar de considerar este conjunto (que conta com quatro indivíduos) como contemporâneo dos restantes materiais associados.

\subsection{As ânforas de produção indeterminada}

Entre o conjunto anfórico dos contextos republicanos do Monte Molião existem ainda 15 indivíduos aos quais não foi possível adscrever, de forma concreta, uma produção específica (fig. 28).

Destes, quatro pertencem a ânforas que integram o tipo Mañá C2, tendo alguns deles sido classificados, em artigos anteriores, como produções de Marismas (Arruda e Pereira 2010). Contudo, actualmente pensamos ser também de considerar a possibilidade de se tratar de produções da área de Málaga.

Outros três exemplares correspondem ao tipo Dressel 1. Neste caso, a indeterminação da área de produção é mais ampla, podendo abranger todo o Mediterrâneo Central e Ocidental, não se descartando a possibilidade de se tratar de produções africanas. 


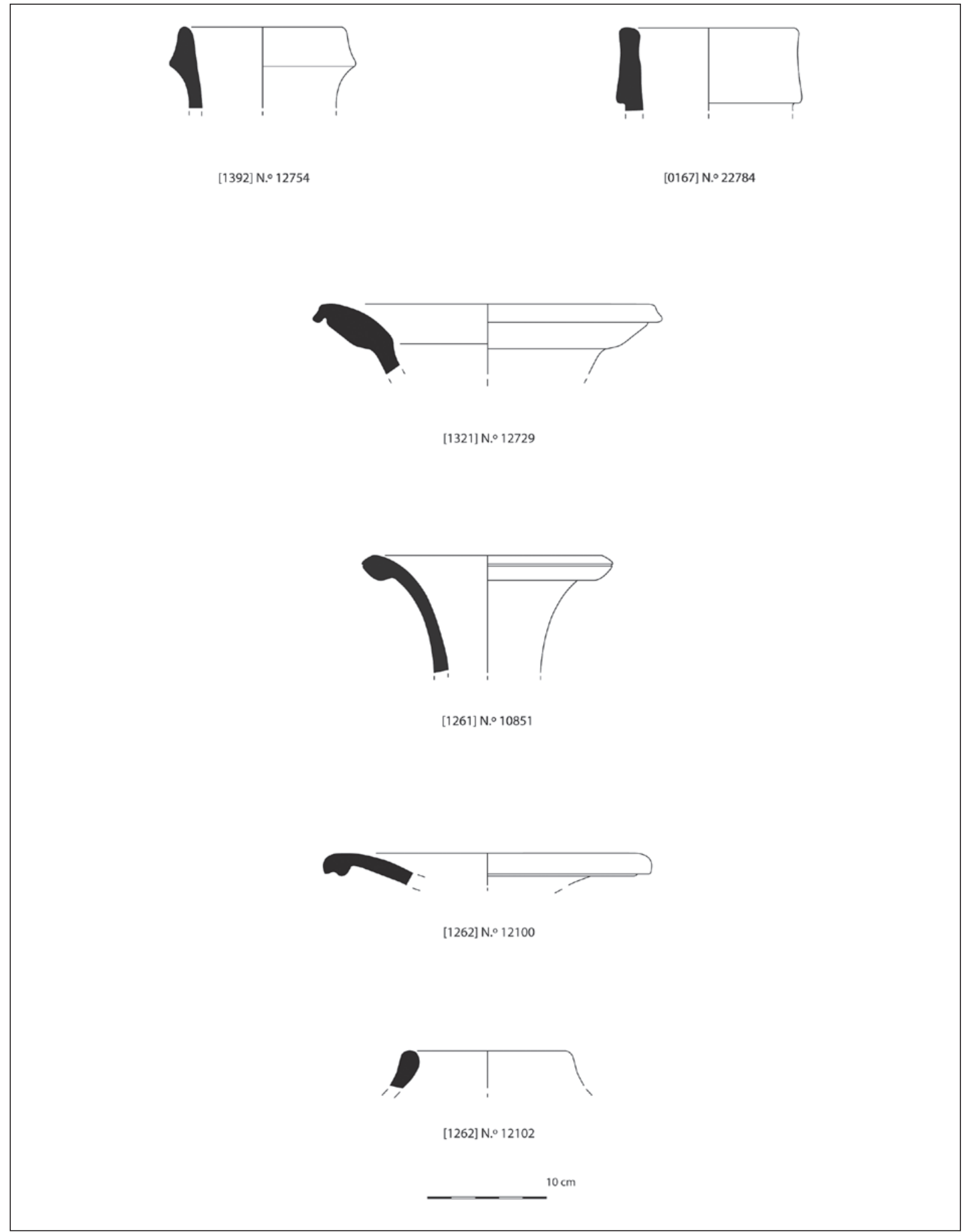

Figura 28. Ânforas de produção indeterminada dos contextos republicanos de Monte Molião: Dressel 1 (12754 e 22784), Mañá C2 (12729, 10851 e 12100) e Mañá Pascual A4 (12102).

ISSN: $1133-4525$ ISSN-e: 2255-3924 


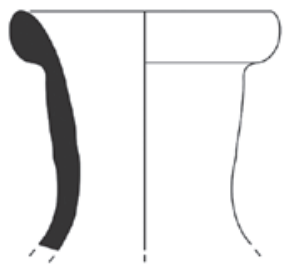

$[1278]$ N. .12408

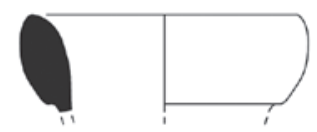

[1274] N. 11846

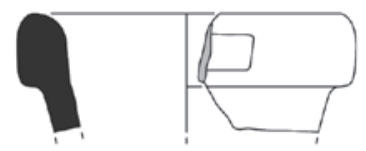

[1101] N.o 10482

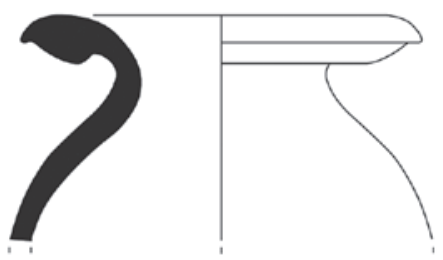

$[103=108] N .021526 / 20989$

$10 \mathrm{~cm}$
Duas ânforas de tipo Mañá-Pascual A4 foram também incluídas neste grupo. Neste caso, e ainda que a produção no Extremo Ocidente seja inquestionável, não é possível, de momento, especificar uma área concreta.

Em relação aos restantes seis indivíduos, nem o estado de fragmentação dos exemplares permitiu a sua integração nos tipos anfóricos conhecidos, nem as características das pastas possibilitam a proposta de áreas de produção concretas.

\subsection{Outras considerações}

Uma última referência deve ser feita ao que considerámos materiais intrusivos e/ou residuais (fig. 29).

Nos níveis conservados da época romano republicana de Monte Molião foram encontrados fragmentos de ânforas que são habitualmente datadas da Idade do Ferro e que, por isso mesmo, foram por nós considerados como residuais. Por outro lado, entre os 235 indivíduos aqui estudados, foram recuperados três bordos passíveis de serem integrados cronologicamente na segunda metade do século I a.n.e., o que manifestamente parece incompatível com a datação dos contextos estudados e, por isso mesmo, foram, de alguma forma, descartados neste estudo.

Neste âmbito, parece imprescindível lembrar que sítios com ocupações de "longa duração", como é o caso em apreço, podem, de facto, apresentar na constituição das suas U.E.s alguns materiais excêntricos à cronologia das mesmas, sem que isso possa ser considerado estranho. Contudo, a distinção entre estes materiais residuais daqueles que são contemporâneos da formação do depósito resulta, por vezes, problemática, especificamente no sul do território peninsular, uma vez que muitos deles, nomeadamente algumas ânforas, são comuns às duas ocupações. No entanto, e considerando os dados disponíveis até ao momento, existem indícios de que certos tipos anfóricos produzidos na área do Estreito, como é o caso dos B/C de Pellicer e Tiñosa, deixaram de ser produzidos durante os momentos finais da Idade do Ferro. A total

Figura 29. Ânforas de produção do Guadalquivir (Oleária Antiga - 12408) e da baía gaditana (Ovóide Gaditana 11846); ânfora itálica (Lamboglia 2 - 10482) e ânfora africana (7.3.1.1. de Ramon Torres - 21526/20989). 
e absoluta ausência destes materiais entre os conjuntos artefactuais republicanos de sítios que, seguramente, não apresentam uma ocupação anterior com registo de importação destes tipos, como é o caso de Lisboa, Valência, Tarraco e acampamentos numantinos, parece indicar que estas ânforas não atingem o período romano. Infelizmente, para os restantes materiais, concretamente as ânforas de tipo D de Pellicer, Mañá-Pascual A4 e Carmona, é difícil assegurar uma cronologia concreta, uma vez que se é verdade que a produção e o consumo se iniciam durante a Idade do Ferro, também é certo que eles se prolongaram durante a época romano-republicana. Assim sendo, os exemplares destes últimos tipos foram incluídos no faseamento romano e estudados neste trabalho, ainda que se admita a possibilidade de alguns deles corresponderem a materiais residuais.

Em relação aos materiais intrusivos, ou seja, mais recentes do que a formação do nível, trata-se apenas de três exemplares, dois dos quais produzidos na área do Guadalquivir, correspondendo a ânforas do tipo Haltern 70, e um outro que parece integrar-se entre o tipo recém definido como Castelinho 1 (Parreira 2009).

Como veremos já de seguida, a existência de uma ocupação da segunda metade do século I a.n.e., ainda que escassamente documentada, quer em termos de espólio quer ao nível de contextos preservados, justifica o aparecimento destes materiais, que surgem em estratos mais antigos certamente devido a fenómenos pósdeposicionais.

Esta ocupação tardia de época republicana está mal representada a nível estratigráfico. Em todo o faseamento, apenas a seis Unidades Estratigráficas, que correspondem a um momento de utilização do que foi interpretado como um espaço de arruamento durante as fases republicanas anteriores, foi possível atribuir esta cronologia. Consistem, especificamente, nos três momentos de enchimento (U.E.s [1278], [1274] e [1273] ) de uma vala (U.E. [1275]) - os únicos níveis que forneceram materiais arqueológicos), aos quais estariam associadas duas áreas de combustão (U.E.s [1110] e [1276]). Dentro destes estratos, e no que se refere aos contentores anfóricos (4 NMI), permanecem ainda ânforas itálicas do tipo Dressel 1 (2 NMI), estando contudo já associadas a uma ovoide gaditana (1 NMI) e a uma oleária antiga (1 NMI), esta produzida na área do Guadalquivir. Estes dados permitem atribuir a este momento uma cronologia mais tardia relativamente aos já descritos neste trabalho, que poderá centrar-se em meados do séc. I a.n.e. (García 1998, Almeida 2008).
Tabelas de distribuição das ânforas de acordo com os contextos estratigráficos analisados. Ânforas dos contextos republicanos de Monte Molião (235 NMI) - distribuição por U.E.s

Tabela 1. Sector A - U.E. [159] - Ânforas (9 NMI)

\begin{tabular}{|c|c|c|}
\hline Forma & Fabrico & NMI \\
\hline Castro Marim 1 & Baía de Cádis & 1 \\
\hline D de Pellicer & Baía de Cádis & 1 \\
\hline Dressel 1 & Baía de Cádis & 2 \\
\hline Mañá C2 & Baía de Cádis & 1 \\
\hline Mañá C2 & Cartago / Tunes & 1 \\
\hline Greco-Itálica & Itálico & 1 \\
\hline Dressel 1 & Itálico & 1 \\
\hline Material intrusivo (Haltern 70) & Guadalquivir & 1 \\
\hline
\end{tabular}

Tabela 2. Sector A - U.E. [162] - Ânforas (1 NMI)

\begin{tabular}{|c|c|c|}
\hline Forma & Fabrico & NMI \\
\hline Indeterminada (Mañá C2 ?) & Cartago / Tunes & 1 \\
\hline
\end{tabular}

Tabela 3. Sector A - U.E. [163] - Ânforas (6 NMI)

\begin{tabular}{|c|c|c|}
\hline Forma & Fabrico & NMI \\
\hline Castro Marim 1 & Baía de Cádis & 3 \\
\hline Dressel 1 & Itálico & 1 \\
\hline $\begin{array}{c}\text { Indeterminada } \\
\text { (Greco-Itálica ou Dr. 1) }\end{array}$ & Itálico & 1 \\
\hline Material intrusivo (Castelinho 1) & Baía de Cádis & 1 \\
\hline
\end{tabular}

Tabela 4. Sector A - U.E. [165] - Ânforas (18 NMI)

\begin{tabular}{|c|c|c|}
\hline Forma & Fabrico & NMI \\
\hline Carmona & Baía de Cádis & 1 \\
\hline Castro Marim 1 & Baía de Cádis & 2 \\
\hline Dressel 1 & Baía de Cádis & 3 \\
\hline Mañá C2 & Baía de Cádis & 5 \\
\hline Tripolitana Antiga & Tripolitânia & 2 \\
\hline Dressel 1 & Itálico & 3 \\
\hline $\begin{array}{c}\text { Indeterminada } \\
\text { (Greco-Itálica ou Dr. 1) }\end{array}$ & Itálica & 2 \\
\hline
\end{tabular}


Tabela 5. Sector A - U.E. [167] - Ânforas (4 NMI)

\begin{tabular}{|c|c|c|}
\hline Forma & Fabrico & NMI \\
\hline Indeterminada & Baía de Cádis & 1 \\
\hline Dressel 1 & Itálico & 1 \\
\hline Dressel 1 & Indeterminado & 1 \\
\hline Indeterminada & Indeterminado & 1 \\
\hline
\end{tabular}

Tabela 6. Sector A - U.E. [171] - Ânforas (1 NMI)

\begin{tabular}{|c|c|c|}
\hline Forma & Fabrico & NMI \\
\hline Dressel 1 & Itálico & 1 \\
\hline
\end{tabular}

Tabela 7. Sector A - U.E. [172] - Ânforas (6 NMI)

\begin{tabular}{|c|c|c|}
\hline Forma & Fabrico & NMI \\
\hline 9.1 .1 .1$. & Baía de Cádis & 1 \\
\hline Castro Marim 1 & Baía de Cádis & 2 \\
\hline Mañá C2 & Baía de Cádis & 1 \\
\hline Dressel 1 & Itálico & 1 \\
\hline Material residual (Tiñosa) & Campiña Gaditana & 1 \\
\hline
\end{tabular}

Tabela 8. Sector A - U.E. [174] - Ânforas (1 NMI)

\begin{tabular}{|c|c|c|}
\hline Forma & Fabrico & NMI \\
\hline $\begin{array}{l}\text { Material residual } \\
\text { (B/C de Pellicer) }\end{array}$ & $\begin{array}{c}\text { Ext. Ocidente } \\
\text { Indeterminado }\end{array}$ & 1 \\
\hline
\end{tabular}

Tabela 9. Sector A - U.E. [183] - Ânforas (1 NMI)

\begin{tabular}{|c|c|c|}
\hline Forma & Fabrico & NMI \\
\hline $\begin{array}{l}\text { Material residual } \\
\text { (B/C de Pellicer) }\end{array}$ & $\begin{array}{c}\text { Ext. Ocidente } \\
\text { Indeterminado }\end{array}$ & 1 \\
\hline
\end{tabular}

Tabela 10. Sector A - U.E. [184] - Ânforas (7 NMI)

\begin{tabular}{|c|c|c|}
\hline Forma & Fabrico & NMI \\
\hline Carmona & Baía de Cádis & 1 \\
\hline Castro Marim 1 & Baía de Cádis & 2 \\
\hline Dressel 1 & Itálico & 1 \\
\hline Mañá C2 & Cartago / Tunes & 2 \\
\hline Tripolitana Antiga & Tripolitânia & 1 \\
\hline
\end{tabular}

Tabela 11. Sector A - U.E. [191] - Ânforas (1 NMI)

\begin{tabular}{|c|c|c|}
\hline Forma & Fabrico & NMI \\
\hline $\begin{array}{l}\text { Material residual } \\
(\mathrm{B} / \mathrm{C} \text { de Pellicer })\end{array}$ & Baía de Cádis & 1 \\
\hline
\end{tabular}

Tabela 12. Sector A - U.E. [197] - Ânforas (1 NMI)

\begin{tabular}{|c|c|c|}
\hline Forma & Fabrico & NMI \\
\hline Mañá Pascual A4 & Baía de Cádis & 1 \\
\hline
\end{tabular}

Tabela 13. Sector C - U.E. [1112] - Ânforas (9 NMI) $-2^{\mathrm{a}}$ fase

\begin{tabular}{|c|c|c|}
\hline Forma & Fabrico & NMI \\
\hline Castro Marim 1 & Baía de Cádis & 2 \\
\hline Mañá C2 & Baía de Cádis & 1 \\
\hline Mañá Pascual A4 & Baía de Cádis & 2 \\
\hline Indeterminada & Baía de Cádis & 1 \\
\hline $\begin{array}{c}\text { Indeterminada } \\
\text { (Greco-Itálica ou Dr. 1) }\end{array}$ & Itálico & 1 \\
\hline Indeterminada & Indeterminado & 1 \\
\hline Material residual (Tiñosa) & Campiña Gaditana & 1 \\
\hline
\end{tabular}

Tabela 14. Sector C - U.E. [1132] - Ânforas (1 NMI) $-2^{\mathrm{a}}$ fase

\begin{tabular}{|c|c|c|}
\hline Forma & Fabrico & NMI \\
\hline Dressel 1 & Indeterminada & 1 \\
\hline
\end{tabular}

Tabela 15. Sector C - U.E. [1158] - Ânforas (5 NMI) $-2^{\mathrm{a}}$ fase

\begin{tabular}{|c|c|c|}
\hline Forma & Fabrico & NMI \\
\hline Mañá C2 & Baía de Cádis & 1 \\
\hline Carmona & Baía de Cádis & 1 \\
\hline Dressel 1 & Itálico & 1 \\
\hline Material residual (Tiñosa) & Campiña Gaditana & 1 \\
\hline $\begin{array}{c}\text { Material residual } \\
\text { (B/C de Pellicer) }\end{array}$ & Baía de Cádis & 1 \\
\hline
\end{tabular}

ISSN: 1133-4525 ISSN-e: 2255-3924 http://dx.doi.org/10.12795/spal.2013.i22.05 
Tabela 16. Sector C - U.E. [1159] - Ânforas (1 NMI) $-2^{\mathrm{a}}$ fase

\begin{tabular}{|c|c|c|}
\hline Forma & Fabrico & NMI \\
\hline Indeterminada & Baía de Cádis & 1 \\
\hline
\end{tabular}

Tabela 17. Sector C - U.E. [1207] - Ânforas (2 NMI) $-2^{\mathrm{a}}$ fase

\begin{tabular}{|c|c|c|}
\hline Forma & Fabrico & NMI \\
\hline Mañá Pascual A4 & Baía de Cádis & 2 \\
\hline
\end{tabular}

Tabela 18. Sector C - U.E. [1260] - Ânforas (8 NMI) $-2^{\mathrm{a}}$ fase

\begin{tabular}{|c|c|c|}
\hline Forma & Fabrico & NMI \\
\hline Castro Marim 1 & Baía de Cádis & 1 \\
\hline D de Pellicer & Baía de Cádis & 1 \\
\hline Mañá C2 & Baía de Cádis & 3 \\
\hline Dressel 1 & Baía de Cádis & 1 \\
\hline Dressel 1 & Itálico & 2 \\
\hline
\end{tabular}

Tabela 19. Sector C - U.E. [1261] - Ânforas (5 NMI) $-2^{\mathrm{a}}$ fase

\begin{tabular}{|c|c|c|}
\hline Forma & Fabrico & NMI \\
\hline Indeterminada & Baía de Cádis & 1 \\
\hline Dressel 1 & Itálico & 3 \\
\hline Mañá C2 & Indeterminado & 1 \\
\hline
\end{tabular}

Tabela 20. Sector C - U.E. [1262] - Ânforas (9 NMI) $-2^{\mathrm{a}}$ fase

\begin{tabular}{|c|c|c|}
\hline Forma & Fabrico & NMI \\
\hline Castro Marim 1 & Baía de Cádis & 1 \\
\hline Mañá C2 & Baía de Cádis & 4 \\
\hline Indeterminado & Baía de Cádis & 1 \\
\hline $\begin{array}{c}\text { Indeterminada } \\
\text { (Greco-Itálica ou Dr. 1) }\end{array}$ & Itálico & 1 \\
\hline Mañá C2 & Indeterminado & 1 \\
\hline Mañá Pascual A4 & Indeterminado & 1 \\
\hline
\end{tabular}

ISSN: 1133-4525 ISSN-e: 2255-3924

http://dx.doi.org/10.12795/spal.2013.i22.05
Tabela 21. Sector C - U.E. [1268] - Ânforas (2 NMI) $-2^{\mathrm{a}}$ fase

\begin{tabular}{|c|c|c|}
\hline Forma & Fabrico & NMI \\
\hline Mañá C2 & Baía de Cádis & 1 \\
\hline Dressel 1 & Itálico & 1 \\
\hline
\end{tabular}

Tabela 22. Sector C - U.E. [1269] - Ânforas (16 NMI) $-2^{\mathrm{a}}$ fase

\begin{tabular}{|c|c|c|}
\hline Forma & Fabrico & NMI \\
\hline 9.1.1.1. & Baía de Cádis & 1 \\
\hline Castro Marim 1 & Baía de Cádis & 4 \\
\hline Mañá C2 & Baía de Cádis & 4 \\
\hline Indeterminada & Baía de Cádis & 1 \\
\hline Greco-Itálica & Itálico & 1 \\
\hline Dressel 1 & Itálico & 3 \\
\hline Mañá C2 & $\begin{array}{c}\text { Ext. Ocidente } \\
\text { Indeterminado }\end{array}$ & 1 \\
\hline $\begin{array}{c}\text { Material residual } \\
\text { (B/C de Pellicer) }\end{array}$ & $\begin{array}{c}\text { Ext. Ocidente } \\
\text { Indeterminado }\end{array}$ & 1 \\
\hline
\end{tabular}

Tabela 23. Sector C - U.E. [1277] - Ânforas (3 NMI) $-2^{\mathrm{a}}$ fase

\begin{tabular}{|c|c|c|}
\hline Forma & Fabrico & NMI \\
\hline Mañá C2 & Baía de Cádis & 2 \\
\hline Mañá C2 & Cartago / Tunes & 1 \\
\hline
\end{tabular}

Tabela 24. Sector C - U.E. [1279] - Ânforas (5 NMI) $-2^{\mathrm{a}}$ fase

\begin{tabular}{|c|c|c|}
\hline Forma & Fabrico & NMI \\
\hline Castro Marim 1 & Baía de Cádis & 2 \\
\hline D de Pellicer & Baía de Cádis & 2 \\
\hline Dressel 1 & Itálico & 1 \\
\hline
\end{tabular}

Tabela 25. Sector C - U.E. [1281] - Ânforas (6 NMI) $-2^{\mathrm{a}}$ fase

\begin{tabular}{|c|c|c|}
\hline Forma & Fabrico & NMI \\
\hline 9.1 .1 .1$. & Baía de Cádis & 1 \\
\hline Castro Marim 1 & Baía de Cádis & 1 \\
\hline
\end{tabular}




\begin{tabular}{|c|c|c|}
\hline Forma & Fabrico & NMI \\
\hline D de Pellicer & Baía de Cádis & 1 \\
\hline Mañá C2 & Baía de Cádis & 1 \\
\hline Dressel 1 & Itálico & 2 \\
\hline
\end{tabular}

Tabela 26. Sector C - U.E. [1285] - Ânforas (4 NMI) $-1^{\mathrm{a}}$ fase

\begin{tabular}{|c|c|c|}
\hline Forma & Fabrico & NMI \\
\hline Mañá C2 & Baía de Cádis & 3 \\
\hline $\begin{array}{c}\text { Indeterminada } \\
\text { (Greco-Itálica ou Dr. 1) }\end{array}$ & Itálico & 1 \\
\hline
\end{tabular}

Tabela 27. Sector C - U.E. [1287] - Ânforas (11 NMI) $-2^{\mathrm{a}}$ fase

\begin{tabular}{|c|c|c|}
\hline Forma & Fabrico & NMI \\
\hline Castro Marim 1 & Baía de Cádis & 2 \\
\hline Mañá C2 & Baía de Cádis & 8 \\
\hline Indeterminada & Baía de Cádis & 1 \\
\hline
\end{tabular}

Tabela 28. Sector C - U.E. [1291] - Ânforas (5 NMI) $-2^{\mathrm{a}}$ fase

\begin{tabular}{|c|c|c|}
\hline Forma & Fabrico & NMI \\
\hline Indeterminada & Baía de Cádis & 1 \\
\hline Mañá C2 & Cartago / Tunes & 2 \\
\hline $\begin{array}{c}\text { Indeterminada } \\
\text { (Greco-Itálica ou Dr. 1) }\end{array}$ & Itálico & 1 \\
\hline Material residual (Tiñosa) & Campiña Gaditana & 1 \\
\hline
\end{tabular}

Tabela 29. Sector C - U.E. [1293] - Ânforas (3 NMI) $-2^{\mathrm{a}}$ fase

\begin{tabular}{|c|c|c|}
\hline Forma & Fabrico & NMI \\
\hline Mañá C2 & Baía de Cádis & 1 \\
\hline Dressel 1 & Itálico & 1 \\
\hline Material residual (B/C de Pellicer) & Baía de Cádis & 1 \\
\hline
\end{tabular}

Tabela 30. Sector C - U.E. [1295] - Ânforas (1 NMI) $-1^{\text {a }}$ fase

\begin{tabular}{|c|c|c|}
\hline Forma & Fabrico & NMI \\
\hline Indeterminada (Mañá C2 ?) & Cartago / Tunes & 1 \\
\hline
\end{tabular}

Tabela 31. Sector C - U.E. [1297] - Ânforas (5 NMI) $-1^{\mathrm{a}}$ fase

\begin{tabular}{|c|c|c|}
\hline Forma & Fabrico & NMI \\
\hline Mañá C2 & Baía de Cádis & 2 \\
\hline Mañá C2 & Cartago/Tunes & 1 \\
\hline Dressel 1 & Itálico & 1 \\
\hline Material residual (Tiñosa) & Campiña Gaditana & 1 \\
\hline
\end{tabular}

Tabela 32. Sector C - U.E. [1299] - Ânforas (7 NMI) $-1^{\mathrm{a}}$ fase

\begin{tabular}{|c|c|c|}
\hline Forma & Fabrico & NMI \\
\hline D de Pellicer & Baía de Cádis & 1 \\
\hline Mañá C2 & Baía de Cádis & 1 \\
\hline Indeterminada & Baía de Cádis & 1 \\
\hline Mañá C2 & Cartago/Tunes & 1 \\
\hline Dressel 1 & Itálico & 3 \\
\hline
\end{tabular}

Tabela 33. Sector C - U.E. [1301] - Ânforas (3 NMI) $-1^{\mathrm{a}}$ fase

\begin{tabular}{|c|c|c|}
\hline Forma & Fabrico & NMI \\
\hline Castro Marim 1 & Baía de Cádis & 1 \\
\hline Mañá Pascual A4 & Indeterminada & 1 \\
\hline Material residual (Tiñosa) & Campiña Gaditana & 1 \\
\hline
\end{tabular}

Tabela 34. Sector C - U.E. [1303] - Ânforas (5 NMI) $-1^{\text {a }}$ fase

\begin{tabular}{|c|c|c|}
\hline Forma & Fabrico & NMI \\
\hline 9.1 .1 .1 & Baía de Cádis & 1 \\
\hline D de Pellicer & Baía de Cádis & 1 \\
\hline Mañá C2 & Cartago / Tunes & 1 \\
\hline Material residual (Tiñosa) & Campiña Gaditana & 1 \\
\hline $\begin{array}{c}\text { Material residual } \\
\text { (B/C de Pellicer) }\end{array}$ & Baía de Cádis & 1 \\
\hline
\end{tabular}

ISSN: 1133-4525 ISSN-e: 2255-3924 http://dx.doi.org/10.12795/spal.2013.i22.05 
Tabela 35. Sector C - U.E. [1304] - Ânforas (4 NMI) $-2^{\mathrm{a}}$ fase

\begin{tabular}{|c|c|c|}
\hline Forma & Fabrico & NMI \\
\hline D de Pellicer & Baía de Cádis & 1 \\
\hline Mañá C2 & Cartago / Tunes & 1 \\
\hline Dressel 1 & Itálico & 1 \\
\hline Material residual (Tiñosa) & Campiña Gaditana & 1 \\
\hline
\end{tabular}

Tabela 36. Sector C - U.E. [1308] - Ânforas (7 NMI) $-1^{\mathrm{a}}$ fase

\begin{tabular}{|c|c|c|}
\hline Forma & Fabrico & NMI \\
\hline Carmona & Baía de Cádis & 1 \\
\hline Mañá C2 & Cartago / Tunes & 1 \\
\hline Dressel 1 & Itálico & 4 \\
\hline Material residual (Tiñosa ?) & Campiña Gaditana & 1 \\
\hline
\end{tabular}

Tabela 37. Sector C - U.E. [1316] - Ânforas (3 NMI) $-2^{\mathrm{a}}$ fase

\begin{tabular}{|c|c|c|}
\hline Forma & Fabrico & NMI \\
\hline Mañá C2 & Cartago / Tunes & 1 \\
\hline Greco-Itálica & Itálico & 1 \\
\hline
\end{tabular}

Tabela 38. Sector C - U.E. [1318] - Ânforas (1 NMI) $-1^{\mathrm{a}}$ fase

\begin{tabular}{|c|c|c|}
\hline Forma & Fabrico & NMI \\
\hline Indeterminada (Greco-Itálica ou Dr. 1) & Itálico & 1 \\
\hline
\end{tabular}

Tabela 39. Sector C - U.E. [1321] - Ânforas (2 NMI) $-1^{\mathrm{a}}$ fase

\begin{tabular}{|c|c|c|}
\hline Forma & Fabrico & NMI \\
\hline $\begin{array}{c}\text { Indeterminada } \\
\text { (Greco-Itálica ou Dr. 1) }\end{array}$ & Itálico & 1 \\
\hline Mañá C2 & Indeterminada & 1 \\
\hline
\end{tabular}

Tabela 40. Sector C - U.E. [1325] - Ânforas (1 NMI) $-2^{\mathrm{a}}$ fase

\begin{tabular}{|c|c|c|}
\hline Forma & Fabrico & NMI \\
\hline Dressel 1 & Itálico & 1 \\
\hline
\end{tabular}

ISSN: 1133-4525 ISSN-e: 2255-3924

http://dx.doi.org/10.12795/spal.2013.i22.05
Tabela 41. Sector C - U.E. [1329] - Ânforas (5 NMI) $-1^{\mathrm{a}}$ fase

\begin{tabular}{|c|c|c|}
\hline Forma & Fabrico & NMI \\
\hline Mañá C2 & Cartago / Tunes & 4 \\
\hline Dressel 1 & Itálico & 1 \\
\hline
\end{tabular}

Tabela 42. Sector C - U.E. [1334] - Ânforas (3 NMI) $-2^{\mathrm{a}}$ fase

\begin{tabular}{|c|c|c|}
\hline Forma & Fabrico & NMI \\
\hline Castro Marim 1 & Baía de Cádis & 1 \\
\hline D de Pellicer & Baía de Cádis & 1 \\
\hline Indeterminada (Mañá C2 ?) & Cartago / Tunes & 1 \\
\hline
\end{tabular}

Tabela 43. Sector C - U.E. [1337] - Ânforas (2 NMI) $-1^{\mathrm{a}}$ fase

\begin{tabular}{|c|c|c|}
\hline Forma & Fabrico & NMI \\
\hline Indeterminada & Baía de Cádis & 1 \\
\hline Dressel 1 & Itálico & 1 \\
\hline
\end{tabular}

Tabela 44. Sector C - U.E. [1384] - Ânforas (2 NMI) $-1^{\mathrm{a}}$ fase

\begin{tabular}{|c|c|c|}
\hline Forma & Fabrico & NMI \\
\hline $\begin{array}{c}\text { Indeterminada } \\
\text { (Greco-Itálica ou Dr. 1) }\end{array}$ & Itálico & 1 \\
\hline Material residual (Tiñosa) & Campiña Gaditana & 1 \\
\hline
\end{tabular}

Tabela 45. Sector C - U.E. [1389] - Ânforas (7 NMI) $-1^{\text {a }}$ fase

\begin{tabular}{|c|c|c|}
\hline Forma & Fabrico & NMI \\
\hline Mañá C2 & Cartago / Tunes & 3 \\
\hline $\begin{array}{c}\text { Indeterminada } \\
\text { (Greco-Itálica ou Dr. 1) }\end{array}$ & Itálico & 1 \\
\hline Material residual (Tiñosa) & Campiña Gaditana & 3 \\
\hline
\end{tabular}

Tabela 46. Sector C - U.E. [1392] - Ânforas (2 NMI) $-1^{\mathrm{a}}$ fase

\begin{tabular}{|c|c|c|}
\hline Forma & Fabrico & NMI \\
\hline Indeterminada & Baía de Cádis & 1 \\
\hline Dressel 1 & Indeterminado & 1 \\
\hline
\end{tabular}


Tabela 47. Sector C - U.E. [1413] - Ânforas (4 NMI) $-2^{\mathrm{a}}$ fase

\begin{tabular}{|c|c|c|}
\hline Forma & Fabrico & NMI \\
\hline Castro Marim 1 & Baía de Cádis & 1 \\
\hline Mañá C2 & Baía de Cádis & 1 \\
\hline Dressel 1 & Itálico & 1 \\
\hline Indeterminada & Indeterminado & 1 \\
\hline
\end{tabular}

Tabela 48. Sector C - U.E. [1421] - Ânforas (4 NMI) $-2^{\mathrm{a}}$ fase

\begin{tabular}{|c|c|c|}
\hline Forma & Fabrico & NMI \\
\hline Indeterminada & Baía de Cádis & 1 \\
\hline Dressel 1 & Itálico & 2 \\
\hline Indeterminada & Indeterminado & 1 \\
\hline Material intrusivo (Haltern 70) & Guadalquivir & 1 \\
\hline
\end{tabular}

Tabela 49. Sector C - U.E. [1434=1437] - Ânforas (7 NMI) $-2^{\mathrm{a}}$ fase

\begin{tabular}{|c|c|c|}
\hline Forma & Fabrico & NMI \\
\hline Castro Marim 1 & Baía de Cádis & 1 \\
\hline Mañá C2 & Baía de Cádis & 2 \\
\hline Dressel 1 & Baía de Cádis & 1 \\
\hline Greco-Itálica & Itálico & 1 \\
\hline Indeterminada & Indeterminado & 1 \\
\hline Material residual (Tiñosa) & Campiña Gaditana & 1 \\
\hline
\end{tabular}

Tabela 50. Sector C - U.E. [1436] - Ânforas (3 NMI) $-2^{\mathrm{a}}$ fase

\begin{tabular}{|c|c|c|}
\hline Forma & Fabrico & NMI \\
\hline Tripolitana Antiga & Tripolitânia & 1 \\
\hline $\begin{array}{c}\text { Indeterminada (Greco-Itálica } \\
\text { ou Dr. 1) }\end{array}$ & Itálico & 1 \\
\hline Material residual (Tiñosa) & Campiña Gaditana & 1 \\
\hline
\end{tabular}

SPAL 22 (2013): 101-141
Tabela 51. Sector C - U.E. $[1440=1448]$ - Ânforas (5 NMI) $-1^{a}$ fase

\begin{tabular}{|c|c|c|}
\hline Forma & Fabrico & NMI \\
\hline Greco-Itálica & Itálico & 1 \\
\hline Dressel 1 & Itálico & 1 \\
\hline $\begin{array}{c}\text { Indeterminada (Greco-Itálica } \\
\text { ou Dr. 1) }\end{array}$ & Itálico & 1 \\
\hline Indeterminada & Indeterminado & 1 \\
\hline Material residual (Tiñosa) & Campiña Gaditana & 1 \\
\hline
\end{tabular}

\section{DISCUSSÃO}

Considerando as balizas cronológicas tradicionalmente estabelecidas para o conjunto anfórico estudado, a ocupação romano-republicana de Monte Molião estende-se, em sentido lato, entre o início do último quartel do século II a.n.e. e o primeiro quartel do século seguinte.

No entanto, considerando as diferenças que pudemos observar entre as três fases republicanas identificadas no Sector C, propomos para a mais antiga uma datação centrada no último quartel do século II a.n.e., sendo a segunda possivelmente de um momento mais tardio, que poderá já englobar as duas primeiras décadas da centúria seguinte. A ocupação antiga de época romana termina no final da República. Os dados em que alicerçamos esta nossa proposta cronológica são de natureza diversa.

Em primeiro lugar, destacamos uma alteração nos ritmos de importação da cerâmica campaniense entre a primeira e a segunda fase de ocupação (Dias 2010). Apesar de a totalidade dos materiais recolhidos ao longo das várias campanhas de escavação ainda não estar devidamente analisado, podemos avançar que, no primeiro momento, a campaniense do tipo A é claramente predominante sobre as produções calenas, alterando-se estas percentagens significativamente na fase seguinte, assistindo-se a um maior equilíbrio entre ambas as produções.

A nível formal, contudo, os tipos identificados encontram-se presentes em ambos os momentos. Assim, na primeira fase, entre a campaniense de tipo A identificaram-se as formas 5, 5/7, 6, 27, 31, 36 e 48A de Lamboglia, resumindo-se as produções calenas associadas a este momento às formas $1,3,5,5 / 7$ e 7 de Lamboglia, 
e estando ainda presente um fragmento de campaniense de pasta cinzenta, classificado como forma 5 de Lamboglia (Dias 2010). Na segunda fase, o repertório da campaniense de tipo A integra as formas 5/7, 6, 8B, 25, 31 e 36 de Lamboglia e o grupo da campaniense de Cales é composto pelas formas 1, 2, 3, 4, 5, 5/7, 7 de Lamboglia, havendo ainda a registar um fragmento de campaniense de tipo B etrusco, possivelmente da forma 4 de Lamboglia, encerrando o conjunto com dois fragmentos de campaniense de pasta cinzenta, da forma 5 de Lamboglia e do tipo 3151 de Morel (Dias 2010).

A análise da distribuição dos contentores anfóricos entre as duas fases republicanas também permite assinalar algumas diferenças. As mais notáveis relacionam-se, como já foi referido anteriormente, com um notável aumento das importações da baía de Cádis durante o momento mais tardio (entre a totalidade do conjunto anfórico, passa de 24,14\% na Fase 1 para 56,20\% na Fase 2). Contudo, as restantes produções, itálicas e africanas, permanecem no registo artefactual, assistindo-se inclusive a um aumento, em números absolutos, dos contentores do primeiro tipo.

Também ao nível formal deve destacar-se um crescimento exponencial das formas gaditanas Mañá C2 e Castro Marim 1, que passam a constituir os tipos predominantes na fase mais tardia.

Os produtos do Guadalquivir só se registam a partir de meados do século I a.n.e, quando as importações diminuem e os níveis de ocupação escasseiam, o que parece indicar um declínio acentuado do sítio.

A cronologia do último quartel do século II a.n.e. é, sobretudo, suportada pelo conjunto anfórico, concretamente pela morfologia das importações itálicas. Porém, gostaríamos de destacar o facto de esta datação poder eventualmente recuar ainda para os finais do $3^{\circ}$ quartel, o que só não assumimos, por que o número de greco-itálicas é consideravelmente mais reduzido do que o que foi encontrado em sítios a que foi atribuída esta cronologia. Com efeito, quer nos níveis fundacionais de Lisboa, quer nos de Valência ou de Tarragona, datados em torno a 140/130 a.n.e., a presença de greco-itálicas face às de transição e Dressel 1 é significativa em termos numéricos, ainda que as primeiras nunca ultrapassem as restantes. A situação de Monte Molião é diversa, mesmo atendendo ao facto de a classificação ter tido por base os parâmetros definidos por Molina Vidal e não os de Gateau, como aconteceu por exemplo em Lisboa.

Também as ânforas norte africanas ajudaram na definição da cronologia do início da ocupação republicana, uma vez que abundam nos contextos mais profundos. A recolha, ainda que descontextualizada, de uma ânfora de tipo 7.3.1.1. seria também um argumento a considerar no momento de recuar a cronologia (fig. 29). Mas, uma vez mais, foi o conjunto dos espólios e não uma peça individualmente que nos norteou na atribuição de uma datação concreta.

\section{CONCLUSÕES}

De acordo com os dados apresentados e discutidos anteriormente, o início do último quartel do século II a.n.e. parece pois ser a data mais plausível para a instalação de populações romanizadas no sítio, o que possibilita a discussão de outras questões que se relacionam com a própria romanização do sul de Portugal.

Em primeiro lugar, deve dizer-se que parece indiscutível o carácter não militar da ocupação. De facto, a existência de níveis pré-romanos, o urbanismo, e, também, a ausência de armas, apontam nesse sentido.

Por outro lado, deve insistir-se que os dados de Monte Molião se associam aos que já estavam disponíveis para Faro e para Castro Marim, mostrando uma romanização tardia dos territórios meridionais, ligeiramente posterior à do vale do Tejo, a última conectada com a Campanha militar de Décimo Júnio Brutus. A ideia de que o percurso, a direcção e a rota desta última se devia ao facto de as áreas mais a sul estarem já integradas na Província da Ulterior parece portanto de descartar, ainda que a romanização do Algarve não avance tanto como já foi proposto por uma de nós em artigo assinado em colaboração com Luís Gonçalves (Arruda e Gonçalves 1993).

Esta ocupação republicana de Monte Molião prolongou-se nos mesmos espaços, que sofreram remodelações, até às duas primeiras décadas do século I a.n.e. As alterações no registo material apontam para uma cada vez maior influência de Cádis no abastecimento de produtos alimentares, concretamente dos produtos piscícolas, com a diminuição acentuada das importações africanas e mais ténue das itálicas.

Ainda que se tenha documentado uma fase tardia de ocupação republicana, a verdade é que os dados indicam que ela é quase inexpressiva e não se evidencia através da construção de estruturas. Assim, os elementos de que dispomos permitem admitir que os edifícios construídos no início do último quartel do século II a.n.e. e utilizados, ainda que sofrendo remodelações várias, até ao final do primeiro quartel do século seguinte foram abandonados repentinamente. É o que fica demonstrado pelo estado de conservação das próprias 
ânforas, bem como pela inexistência de sedimentos no seu interior, no sector A. A ocorrência de um sismo pode ter estado na origem desta situação, sismo esse que foi já defendido tendo em consideração as deformações, com fracturação e rotação, das paredes dos compartimentos do sector C (Gomes 2010). Outros estudos sobre Monte Molião, concretamente os que incidiram sobre a fauna malacológica, provaram também uma alteração paleo-ambiental no final da fase republicana que foi também interpretada através de um fenómeno natural (tsunami após sismo) que teria provocado o rompimento do cordão dunar já então formado (Detry e Arruda no prelo). Contudo, as informações para grandes terramotos com tsunami associado foram confirmadas na região de Huelva apenas para o final do século III a.n.e. (218/216 e 210/209 a.n.e.) (Ruiz et al. 2008), havendo poucas evidências para o que terá ocorrido em cerca de 60 a.n.e., que, a confirmarem-se os dados de Monte Molião, pode ter tido lugar alguns anos antes.

Por fim, importa ainda discutir o facto do evidente declínio do sítio a partir de meados do século I a.n.e., declínio esse que se prolonga ainda durante boa parte da primeira metade do século seguinte, e que se manifesta pela escassez de importações, bem como pela ausência de construções com dimensão e peso significativos. Se por um lado, o sismo/tsunami poderia justificar a situação, por outro também é verdade que seria expectável que tivesse dado origem a um fenómeno de reconstrução em grande escala, o que, manifestamente não aconteceu, considerando os dados actualmente disponíveis. Sabemos que o sítio permaneceu habitado quer durante a fase final da República quer ao longo de toda a dinastia julio-cláudia, mas não atingiu, nesses momentos, o desenvolvimento dos anteriores nem do que ocorreu sob os Flávios e os Antoninos.

Assim, parece possível admitir que o apoio concedido por Laccobriga aos partidários de Sertório durante a Guerra Civil e a ajuda recebida das tropas deste último durante o cerco relatado por Plutarco (Sertorius 13) podem ter originado uma retaliação por parte dos vencedores, retaliação essa que, como foi frequente, se prolongou consideravelmente no tempo. $\mathrm{O}$ empobrecimento da comunidade local pode, na nossa perspectiva, ser interpretado no quadro destes acontecimentos. Talvez seja esta a explicação para o facto de Laccobriga ser um dos raros oppida algarvios com ocupação republicana que não procedeu à cunhagem de moeda, sendo este também um dado a considerar no momento de atribuir uma cronologia a este fenómeno, que assim só pode ter tido lugar a partir de meados do século I a.n.e.

\section{AGRADECIMENTOS}

O presente artigo resulta do Projecto de Investigação "Monte Molião na Antiguidade", desenvolvido na UNIARQ, financiado pela Câmara Muncipal de Lagos e gerido pela Faculdade de Letras de Lisboa.

Ao Rui Parreira, da Direcção Regional de Cultura do Algarve, agradecemos a cedência da fotografía aérea de Monte Molião, que usámos na fig. 2, e à Elena Morán toda a colaboração prestada ao projecto.

\section{BIBLIOGRAFIA}

Alarcão, J. (1976): "Les Amphores", en J. Alarcão e R. Etiènne (eds.), Fouilles de Conimbriga VI Céramique diverses et verres, pp. 79-91. Paris, Difusion du Boccard.

Almeida, R. (2008): Las ánforas del Guadalquivir en Scallabis (Santarém, Portugal). Una aportación al conocimiento de los tipos minoritarios. Collecció Instrumenta, 28. Barcelona, Universidad de Barcelona.

Almeida, R. e Arruda, A.M. (2005): “As ânforas de tipo Mañá C em Portugal”, en Ati del V Congreso Internazionale di Studi Fenici i Punici (Marsala, 2000): 1319-1329. Palermo, Universidad de Palermo.

Arruda, A.M. (1999-2000): Los fenicios en Portugal: Fenicios y mundo indígena en el centro y sur de Portugal. Barcelona, Universidad Pompeu Fabra.

Arruda, A.M. (2007): Laccobriga: A ocupação romana na Baía de Lagos. Lagos, Câmara Municipal de Lagos.

Arruda, A.M. e Almeida, R. (1998): “As ânforas da Classe 32 da Alcáçova de Santarém”. Conimbriga 37: 201-231.

Arruda, A.M. e Almeida, R. (1999): “Importações de vinho itálico para o território português: contextos, cronologias e significado", en Économie et territoire en Lusitanie romaine (Actes du IIIème Table ronde sur la Lusitanie romaine Madrid, 1996), pp. 307-337. Madrid, Casa de Velázquez.

Arruda, A.M. e Gonçalves, L. (1993): "Sobre a romanização do Algarve", en Actas do II Congresso peninsular de História Antiga (Coimbra, 1990), pp. 455465. Coimbra, Universidade de Coimbra.

Arruda, A.M. e Pereira, C. (2008): “As ocupações antigas e modernas do Forte de S. Sebastião (Castro Marim)". Xelb 8: 391-421.

Arruda, A.M. e Pereira, C. (2010): "Fusão e produção: actividades metalúrgicas em Monte Molião 
(Lagos), durante a época romano-republicana". Xelb 10: 695-716.

Arruda, A.M.; Sousa, E.; Bargão, P. e Lourenço, P. (2008): "Monte Molião (Lagos) - Resultados de um projecto em curso". Xelb 8: 161-192.

Arruda, A.M.; Sousa, E. e Lourenço, P. (2010): “A necrópole romana de Monte Molião (Lagos)". Xelb 10: 267-283.

Arruda, A.M.; Viegas, C. e Bargão, P. (2005): “As ânforas da Bética costeira na Alcáçova de Santarém”. Revista Portuguesa de Arqueologia 8(1): 279-297.

Arruda, A.M.; Viegas, C. e Bargão, P. (2010): “A cerâmica comum de produção local de Monte Molião (Lagos)". Xelb 10: 285-304.

Arruda, A.M.; Viegas, C.; Bargão, P. e Pereira, R. (2006): “A importação de preparados de peixe em Castro Marim: da Idade do Ferro à época romana". Setúbal Arqueológica 13: 153-176.

Asensio i Villaró, D. (2010): “El comercio de ánforas itálicas en la Península Ibérica entre los siglos IV e I a.C. y la problemática en torno a las modalidades de producción y distribución". Bollettino di Archeologia on line, volume special B/B8/3: 23-41.

Bargão, P. (2006): As importações anfóricas do Mediterrâneo durante a época romana republicana na Alcáçova de Santarém. Tese de Mestrado. Faculdade de Letras da Universidade de Lisboa. Inédita.

Bargão, P. e Arruda, A.M. (no prelo): "New amphora type called Castro Marim 1", en Actes du VII Congrès International d'Études Phéniciens et Puniques (Hamammet, 2009).

Bechtold, B. (2010): The pottery repertoire from late $6^{\text {th }}$-mid $2^{\text {nd }}$ Century BC Carthage: Observations based on the Bir Messaouda Excavations. Carthage Studies. Gent, Universidad de Gent.

Belén Deamos, M. (2007): “Ánforas de los siglos VIIV en Turdetania". Spal 15: 217-246.

Bernal, D.; Díaz, J.J.; Expósito, J.A.; Sáez, A.M.; Lorenzo, L. e Sáez, A. (2003): Arqueologia y urbanismo. Avance de los hallazgos de época púnica y romana en las obras de la carretera de Camposoto (San Fernando, Cádiz). Cádiz, Universidad de Cádiz.

Bonet Rosado, H.; Fumadó Ortega, I.; Aranegui Gascó, C.; Vives-Ferrándiz Sánchez, J.; Hassini, H. e Kbiri Alaoui, M. (2005): "La ocupación mauritana", en C. Aranegui Gascó (ed.), Lixus-2 Ladera sur. Excavaciones Arqueológicas Marroco-Españolas en la colonia fenicia. Campañas 2000-2003. Saguntum Extra, 6. Valencia, Universitad de Valencia.
Buraca, I. (2005): Civitas Conimbriga: ânforas romanas. Tese de Mestrado. Universidade de Coimbra. Inédita.

Campos Carrasco, J.; Gómez Toscano, F. e Pérez Macías, J. (2007): Ilipa Niebla. Evolución Urbana y ocupación del Territorio. Huelva, Universidad de Huelva.

Carretero Poblete, P. (2004): "Las producciones cerámicas de ánforas tipo "Campamentos Numantinos" y su origen en San Fernando (Cádiz): Los hornos de Pery Junquera", en Figlinae Baeticae: talleres alfareros y producciones cerámicas en la Bética romana (ss. II a.C.-VII d.C.), pp. 427-440. Oxford, Archaeopress.

Detry, C. e Arruda, A.M. (no prelo): “A fauna da Idade do Ferro e Época romana de Monte Molião (Lagos, Algarve). Continuidades e rupturas na dieta alimentar", en Actas do VIII Congresso de Arqueologia do Algarve (Silves 2010).

Dias, V. (2010): A cerâmica campaniense de Monte Molião. Tese de Mestrado. Faculdade de Letras da Universidade de Lisboa. Inédita.

Díaz García, M. (2000): “Tipocronología de los contextos cerámicos tardo-republicanos en Tarraco”. Empuries 52: 201-260.

Diogo, A.M.D. (1993): “Ânforas pré-romanas dos Chões de Alpompé (Santarém)". Estudos Orientais 4: 229-283.

Diogo, A.M.D. e Trindade, L. (1998): “Uma perspectiva sobre Tróia a partir das ânforas. Contribuição para o estudo da produção e circulação das ânforas romanas em território português". O Arqueólogo Português 4(16): 187-220.

Fabião, C. (1987): “Ânforas republicanas de um depósito de Mértola no Museu Nacional de Arqueologia e Etnologia”. O Arqueólogo Português, 4(5): 125-148.

Fabião, C. (1989): Sobre as ânforas do acampamento romano da Lomba do Canho (Arganil). Lisboa, UNIARQ.

Ferrer Albelda, E. (2007): "El territorio de la ciudad bástulo-púnica de Baesippo", en J.L. Lopez Castro (ed.), Las ciudades fenicio-punicas en el Mediterráneo Occidental: 281-314. Almería, Universidad de Almería.

Frutos, G.; Chic; G. e Berriatúa, N. (1988): "Las ánforas de la factoría prerromana de salazones de "Las Redes" (Puerto de Santa Maria, Cádiz)", en Actas del I Congreso Peninsular de Historia Antigua: 295-306. Santiago de Compostela (1986), Santiago de Compostela, Universidad de Santiago de Compostela. 
García Vargas, E. (1998): La producción de ánforas en la Bahía de Cádiz en la Época Romana (Siglos II a.C. $-I V$ d.C.). Sevilla, Gráficas Sol.

García Vargas, E. (2009): "Las ánforas republicanas de Hispalis (Sevilla) y la "cristalización" del repertorio anfórico provincial”, en R. Cruz-Auñón e E. Ferrer Albelda (coords.). Estudios de Prehistoria y Arqueología en homenaje a Pilar Acosta Martínez: 437-464. Sevilla, Universidad de Sevilla.

García Vargas, E. e Bernal, D. (2008): “Ánforas de la Bética”, en D. Bernal e A. Ribera Lancomba (eds.), Cerámicas hispano romanas. Un estado de la cuestión: 661-687. Cádiz, Universidad de Cádiz.

Gateau, F. (1990): “Amphores importées durant le I $\mathrm{I}^{\mathrm{e}} \mathrm{II}^{\mathrm{e}}$ s. av. J.C. dans trois habitats de Provence occidentale: Entremont, le Baou-Roux, Saint-Blaise". Documents d'Archéologie Méridionale 13: 163-183.

Gomes, J. (2010): Estuário da Ribeira de Bensafrim. Leitura geo-arqueossismológica. Tese de Mestrado. Faculdade de Letras da Universidade de Lisboa. Inédita.

González Toray, B.; Torres, J.; Lagóstena, L. e Prieto, O. (2000): "Los inicios de la producción anfórica en la Bahía gaditana en época Republicana: la intervención de urgencia en Avda. Pery Junquera (San Fernando, Cádiz)", en Actas del Congreso Internacional Ex Baetica Amphorae. Conservas, Aceite y Vino de la Bética en el Imperio Romano, pp. 175-186. Sevilla/Écija (1998), Écija, Editorial Gráficas Sol.

Lourenço, P. (2010): A pesca na Antiguidade. O caso de Monte Molião. Tese de Mestrado Tese de Mestrado. Faculdade de Letras da Universidade de Lisboa. Inédita.

Luís, L. (2003): “Ânforas republicanas de Mata-Filhos (Mértola)". Revista Portuguesa de Arqueologia 6(2): 363-382.

Luzón Nogué, J.M. (1973): Excavaciones en Itálica. Estratigrafía en el Pajar de Artillo (Campaña de 1970). Madrid, Comisaría General de Excavaciones Arqueológicas.

Molina Vidal, J. (1997): La dinámica comercial romana entre Italia e Hispania Citerior. Alicante, Universidad de Alicante e Instituto de Cultura Juan Gil-Albert.

Morais, R. (2010): “Ânforas”, en J. Alarcão, P. Carvalho e A. Gonçalves (coords.), Castelo da Lousa Intervenções Arqueológicas de 1997 a 2002. Studia Lusitana 5: 181-218. Mérida, Junta de Extremadura.

Morel, J.P. (2004): "Les amphores importées à Carthage punique", en J. Sanmartí, D. Ugolini, J. Ramón, J. e D. Asensio (eds.), La circulació d'àmfores al Mediterrani ocidental durant la Protohistòria (segles VIII-III aC): aspectes quantitatius $i$ anàlisi de continguts. Actes de la II Reunió Internacional d'Arqueologia (Calafell 2002). Arque Mediterrània 8: 11-23.

Muñoz Vicente, A. (1985): "Las ánforas prerromanas de Cadiz (informe preliminar)”. Anuario Arqueológico de Andalucía/1985(t.III): 471-478.

Parreira, J. (2009): As ânforas romanas de Mesas do Castelinho. Tese de Mestrado. Faculdade de Letras da Universidade de Lisboa. Inédita.

Pellicer Catalán, M. (1978): “Tipología y cronología de las ánforas preromanas del Guadalquivir según el Cerro Macareno (Sevilla)". Habis 9: 365-400.

Perdigones Moreno, L. e Muñoz Vicente, A. (1988): “Excavaciones arqueológicas de urgencia de los hornos púnicos de Torre Alta, San Fernando, Cádiz". Anuario Arqueológico de Andalucía/1988(t. III) t. 3: 106-112.

Pimenta, J. (2005): As ânforas romanas do Castelo de São Jorge. Lisboa, Instituto Português de Arqueologia.

Pimenta, J. e Mendes, H. (2008): "Descoberta do povoado pré-romano de Porto do Sabugueiro (Muge)". Revista Portuguesa de Arqueologia 11(2): 171-194.

Principal, J. (2000): "Vajilla de barniz negro de los Campamentos del Cerco de Numancia (Garray, Soria)", en X. Aquilué, J. García e J. Guitart (coords.), La cerámica de vernís negre deis segles II i I aC: Centres productors mediterranis $i$ comercializado a la Península Ibérica: 269-279. Barcelona, Museo de Mataró, Museu D'Arqueología de CatalunyaEmpúries e Universidad Autónoma de Barcelona.

Ramón Torres, J. (1995): Las ánforas fenicio-punicas del Mediterráneo central y occidental. Barcelona, Universidad de Barcelona.

Ramón Torres, J. (2008): “El comercio púnico en Occidente en época tardo republicana (siglos -II -I). Una perspectiva actual según el tráfico de productos envasados en ánforas", en J. Uroz, J. Noguera e F. Coarelli (eds.), Iberia e Italia: modelos romanos de integración territorial: 67-100. Murcia, Tabularium.

Ribera i Lacomba, A. (1998): La fundación de Valencia. La ciutat a l'època romano republicana (segles II-I a.C.). Estudios Universitarios, 71. Valencia, Institució Alfons el Magnànim.

Ribera i Lacomba, A. (2002): "El urbanismo de la primera Valencia", en Valencia y la primeras ciudades romanas de Hispania, pp. 299-313.Valencia, Ayuntamiento de Valencia.

Ribera i Lacomba, A. e Marín Jordá, C. (2003): "Las importaciones itálicas del nivel de fundación (138 a.C.) de la ciudad romana de Valentia". Rei Cretariae Romanae Fautorum 38: 287-294. 
Ruiz, F.; Abad, M.; Rodríguez Vidal, J.; Cáceres, L.; González Regalado, M.; Carretero, M.; Pozo, M. e Gómez Toscano, F. (2008): “The geological record of the oldest historical tsunamis in southwestern Spain". Rivista Italiana di Paleontologia e Stratigrafia 114(1): 145-154.

Sáez Romero, A. (2008): "El sistema alfarero-salazonero de Gadir/Gades. Notas sobre sus procesos de transformación y adaptación en época helenística". Saguntum 40: 141-160.

Sanmartí Greco, E. (1985): “Las ánforas romanas del campamento numantino de Pena Redonda (Garray, Soria)". Ampurias 47: 130-161.

Sanmartí Greco, E. (1992): "Nouvelles données sur la chronologie du Camp de Renieblas V à Numance (Soria, Castilla-León, Espagne)". Documents d'Archéologie Méridionale 15: 417-431.
Santos, D. (2009): As ânforas pré-romanas do tipo Mañá-Pascual A4 do Castelo de Castro Marim. Tese de Mestrado. Faculdade de Letras da Universidade de Lisboa. Inédita.

Sousa, E. e Serra, M. (2006): "Resultados das intervenções arqueológicas realizadas na zona de protecção do Monte Molião (Lagos)". Xelb 6 (1): 5-20.

Tchernia, A. (1986): Le vin de L'Italie romaine. Essai d'histoire économique d'après les amphores. Paris, Difusion de Boccard.

Viegas, C. (2011): A ocupação romana do Algarve estudo do povoamento e economia do Algarve central e oriental no período romano. Lisboa, Centro de Arqueologia da Universidade de Lisboa.

Wolff, S.R. (1986): "Carthage and the Mediterranean: Imported Amphoras from the Punic Commercial Harbor". Carthage IX(4): 134-153. 